\title{
A influência dos capitais da imigração europeia e dos estrangeiros nos nomes das escolas estaduais em Curitiba
}

\author{
Natália Cristina Granato ${ }^{1}$ \\ Luciana Podlasek ${ }^{2}$
}

\begin{abstract}
Resumo: O presente trabalho procura discutir a relação entre a imigração europeia e os nomes das escolas estaduais regulares em Curitiba, capital do estado do Paraná, analisando quais são os capitais dos homenageados, que também fazem referência a outras etnias estrangeiras. Temos como referência as reflexões sobre o "campo político" do sociólogo francês Pierre Bourdieu e algumas reflexões sobre a o ato de nomear lugares a partir de nomes de pessoas, os chamados antropotopônimos. Investigaremos, dentre as 163 escolas de Curitiba, quais correspondem aos sobrenomes de origem europeia/estrangeira que nomeiam estas escolas. Levantaremos informações como o nome completo da pessoa que nomeia as escolas, sua profissão e atuação e o ano de nomeação e fundação da escola, entre outras, com o objetivo de traçar um perfil prosopográfico destas personalidades homenageadas. Ao analisar os nomes das escolas, pretendemos verificar quais são os atributos dos homenageados escolhidos pelos decretos de nomeação elaborados pelo estado do Paraná dentro do recorte estabelecido e refletir sobre as formas de dominação simbólica inseridas neste processo.
\end{abstract}

Palavras-chave: Imigração; Capitais; Nomes de escolas.

\section{The influence of European immigration and foreign capital on the names of state schools in Curitiba}

\begin{abstract}
This paper aims to discuss the relationship between European immigration and the names of regular state schools in Curitiba, capital of the state of Paraná, analyzing the capitals of the honorees, who also refer to other ethnic groups. We have as reference the reflections on the "political field" of the French sociologist Pierre Bourdieu and some reflections on the act of naming places from the names of people, the so-called anthropotoponyms. We will investigate, among the 163 schools in Curitiba, which correspond to the surnames of European origin/ other ethnic groups that name these schools. We will collect information such as the full name of the person who names the schools, their profession and performance and the year of appointment and foundation of the school, among others, with the aim of outlining a prosopographic profile of these honored personalities. In analyzing the names of the schools, we intend to verify what are the attributes of the honorees chosen by the naming decrees elaborated by the state of Paraná within the established cut and to reflect on the forms of symbolic domination inserted in this process.
\end{abstract}

Keywords: Immigration; Capitals; School names.

\footnotetext{
${ }^{1}$ Doutoranda em Sociologia pela Universidade Federal do Paraná e bolsista da CAPES. Mestre em Sociologia e graduada em Ciências Sociais pela UFPR. Integrante do Núcleo de Estudos Paranaenses na mesma instituição. Bolsista da CAPES. E-mail: nataliagranato@ hotmail.com

${ }^{2}$ Mestranda em Sociologia pela UFPR. Graduada em História pela UFPR. Integrante do Núcleo de Estudos Paranaenses na mesma instituição. Bolsista da CAPES. E-mail: lucianabenario@gmail.com
} 


\section{O que nomeia um lugar? Reflexões sobre motivações toponímicas e de capitais sociais}

$\mathrm{O}$ ato de nomear um lugar público como uma escola tem uma forte carga de poder e isto se reproduz simbolicamente nos indivíduos que circulam e fazem parte desta instituição social. A análise da significação dos nomes dos lugares integra um campo de estudo nas ciências linguísticas que se denomina "toponímia". Tal estudo debruça-se sobre a "estruturação dos motivos ou das fontes geradoras dos nomes de lugares" (DICK, 1990, p.22), que extrapola a dimensão linguística propriamente dita, e integra as dimensões sociais, culturais e políticas que nomeiam os lugares. Por sua vez, os lugares são resultados das experiências humanas, nas quais as pessoas os percebem e os atribuem significados nas relações cotidianas, sendo os mesmos somatórios de relações políticas, emocionais, simbólicas, sociais, entre outras (SANTOS, 2016, p.174). Os lugares também são práticas discursivas e distintivas de poder, pois nomear um lugar é proporcionar reconhecimento. As dimensões simbólicas de nomeação ligam o indivíduo aos lugares onde o mesmo frequenta, enraizando-o aos ambientes sociais de maneira subjetiva, dizendo respeito à "construção da personalidade e da identidade de um indivíduo ou grupo" (SANTOS, 2016, p.175).

No caso das escolas públicas de Curitiba, remetemo-nos à análise dos antropotopônimos, ou seja, aos nomes de lugares que digam respeito aos designativos pessoais, "seja em prenomes ou em apelidos de família, combinadamente ou não" (DICK, 1990, p.285). Segundo Pierre Nora (1993, p.21), o lugar diz respeito à relação entre a memória e a história, tendo em vista que é preciso ter "vontade de memória", incorporando ao lugar uma "aura simbólica". As escolas são lugares que preservam e reproduzem às novas gerações uma "memória coletiva", nas quais a nomeação antropotômica revela "aspectos de autolatria, imodéstia ou desejo de perpetuação de feitos individuais (...)" (DICK, 1990, p.310).

Outra dimensão levada em consideração neste trabalho é o levantamento de capitais sociais e educacionais ${ }^{3}$ que fazem com que um agente se torne um homenageado

\footnotetext{
${ }^{3}$ Em um determinado "campo" social, neste caso, o educacional, os agentes que se encontram no seu interior possuem volumes de "capitais" que determinam a sua posição de forças e prestígio. No campo
} 
como um nome de escola. Para Pierre Bourdieu, todos os "campos" da vida social (sejam eles políticos, econômicos, simbólicos, educacionais, acadêmicos, etc) se definem através de forças e de lutas, sendo os mesmos compostos de agentes com determinadas condutas correspondentes às suas posições na "estrutura da relação de forças" relacionadas aos campos em determinados momentos (BOURDIEU, 2011, p.201).

A análise dos capitais políticos, simbólicos, sociais e educacionais dos agentes que foram homenageados pelo Estado por nomes de escolas é uma forma de mapear as lutas e disputas na sociedade paranaense, que nomeia agentes que fazem referência aos imigrantes. Tal ato reconhece a importância destes grupos na sociedade e na história local, revelando status, prestígio e poder simbólico a estes grupos. Na próxima seção, refletiremos sobre alguns elementos que dizem respeito à imigração europeia no Paraná

\section{A imigração europeia no Paraná e as primeiras experiências colonizadoras}

O fenômeno imigratório no Brasil está diretamente ligado às transformações econômicas, políticas e sociais proporcionadas pela transição do feudalismo para o capitalismo em sua forma consolidada no caso europeu, e, no caso brasileiro, da transição de uma sociedade escravocrata para uma sociedade organizada a partir do trabalho livre (IANNI, 2004, p.138). No século XIX, os efeitos da Revolução Industrial foram sentidos pela população europeia, como o elevado crescimento populacional, o empobrecimento e a proletarização destes contingentes, que viam na imigração para a América uma possibilidade de ascensão social (NADALIN, 2001, p.62). Desta maneira, segundo Sérgio Nadalin (2001, p.62), entre a segunda metade do século XIX e a primeira metade do século XX, aproximadamente 60 milhões de europeus emigraram ao redor do mundo, destinando-se especialmente ao continente americano. Neste contexto é que se criou também um "mercado internacional da força de trabalho" (IANNI, 2004, p.138), fruto do desenvolvimento do capitalismo, tendo como consequência o fim do tráfico internacional de escravos. No Brasil, a força de trabalho escrava foi substituída pela força de trabalho

educacional, "capitais" de grande valia referem-se a capitais educacionais (formação, atuação, publicações, posição institucional, reconhecimento) e sociais (família, prestígio, pertencimento a clubes, etc). 
proveniente da imigração europeia através de incentivos governamentais que visavam o "branqueamento" da população, produto de uma ideologia racista que enxergava na população mestiça o fator causador de atraso da nação brasileira. O Brasil recebeu, do século XIX a 1974, aproximadamente 5 milhões de imigrantes (IANNI, 2004, p.140).

No Paraná, a imigração foi massivamente incentivada em prol da colonização do território e ocupação dos chamados "vazios demográficos", temendo-se a perda de espaço para os argentinos e ataques dos índios botocudos. A colonização do território sob o regime de pequenas propriedades da imigração se dava no contexto de crise do trabalho escravo e das criações de gado e alteração do uso das propriedades, com a ascensão de atividades ervateiras e madeireiras, incremento da urbanização e do mercado interno (NADALIN, 2001). O mercado interno crescente demandava força de trabalho braçal e agrícola para o abastecimento alimentício da população, que desprezava o trabalho agrícola pois o mesmo "era considerado uma atividade de baixo status social, digna apenas de escravos e libertos" (WACHOWICZ, 2001, p.148). No pensamento de Octávio Ianni (2000), quando o regime de trabalho escravo entrou em declínio, toda uma cultura do trabalho como atividade do 'trabalhador escravo' (subordinado, alienado, forçado e compulsório) precisou ser redefinida em termos do trabalho como atividade do 'trabalhador livre', criando uma nova ética do trabalho, através dos imigrantes europeus. Os mesmos, para as classes dominantes locais, tinham uma dupla missão: além de abastecer a população com a produção agrícola, introduzindo novas técnicas, tinham a função pedagógica de ensinar aos nacionais as "virtudes do trabalho" (NADALIN, 2001, p.65).

Nesse contexto, a introdução de grandes levas de população europeia também atendia aos interesses do pensamento para o "branqueamento da raça" no Brasil. A ideia era que, com o povoamento e a miscigenação ocorrendo por meio de grande número de pessoas advindas da Europa, paulatinamente a população brasileira iria absorver as virtudes provenientes dos povos do Hemisfério Norte, e diluir os "vícios" inerentes a nossa formação étnica secular. Tal juízo depreciativo a respeito da formação negra do Brasil (com predominância do indivíduo negro escravizado) não era novo no século XIX, 
mas remonta a todo um imaginário ligado à religiosidade católica medieval ${ }^{4}$. Contudo, o cientificismo oitocentista contribuía para a sedimentação dessas ideias em termos "racionais", introduzindo o postulado que a miscigenação, com grande número de elementos advindos das etnias brancas "superiores", poderia ser a saída para o melhoramento da formação populacional da Nação.

\begin{abstract}
Mas é no pensamento do médico e antropólogo João Baptista Lacerda, frequentemente tido como propagandista mais importante da ideologia do branqueamento, que se articula de forma mais patente a conjunção entre ideário de branqueamento e propagação do Brasil como "paraíso racial". Lacerda foi nomeado pelo então Presidente da República para representar o país no primeiro Congresso Universal das Raças, em 1911, em Londres. Lá, ele defendeu a ideia de que o Brasil já estava a caminho de resolver a sua "questão racial". A imigração e a "seleção sexual" (a preferência por casamento com brancos) deveriam dissolver a "raça negra" num período de 100 anos e, desta forma, transformar o Brasil num dos "principais centros do mundo civilizado". O desaparecimento do negro era visto como uma consequência "lógica" desse processo, como uma questão de tempo: "[...] é lógico supor que num período de um novo século, os mestiços desaparecerão do Brasil, fato que coincidirá com a extinção paralela da raça negra entre nós" (HOFBAUER, 2011, p. 6).
\end{abstract}

Durante o processo de imigração e estabelecimento das populações advindas da Europa, também se manifestavam ideias racistas inerentes à própria diversidade destas etnias, pois, no imaginário de muitos brasileiros e imigrantes (o que foi constatado em especial na cidade de Curitiba), algumas etnias eram carregadas de virtudes (como os alemães, vistos como morigerados, cultos e responsáveis), enquanto outras permaneciam num patamar de inferioridade (exemplo dos poloneses, muitas vezes enxergados como preguiçosos, bêbados, e as mulheres como vulgares e prostitutas) (OLIVEIRA, 2015).

\footnotetext{
${ }^{4}$ Antes de incorporarem as noções raciais, as concepções e imagens a respeito do que era "negro" e "branco" aparecem no discurso católico medieval, carregados de ideais morais e religiosos. A imagem do branco (qualquer que fosse ela: indivíduo, alegoria ou forma da natureza) era associada à pureza, ao bem, ao divino, enquanto a do negro era associada ao sombrio, ao maligno e ao diabólico. Dessa forma, ocorre um processo de associação, onde o pagão se tornou o negro, sombrio, condenável, e o cristão seria seu oposto branco, missionário da luz e do bem. Com a implantação do sistema colonial escravista na América a partir do século XVI, a associação da imagem do negro (do mal) com a escravidão se deu a tal ponto, que certas populações escravizadas, como os indígenas, também eram simplesmente classificadas como negras, devido a forte carga ideológica religiosa da época. Mesmo no contexto da pós-abolição da escravidão no Brasil, no final do século XIX, tal referencial não desapareceu do imaginário das populações que aqui viviam. Ao contrário, tal discurso racista foi em certa medida incorporado e reforçado por novos argumentos, que viriam justamente do campo científico, com o desenvolvimento das teorias eugenistas (HOFBAUER, 2011).
} 
No Paraná, a primeira iniciativa local de colonização não-portuguesa deu-se em 1829, por ação do tropeiro e latifundiário João da Silva Machado, no estabelecimento de colonos alemães em Rio Negro, em prol da expulsão dos indígenas xokleng dos seus territórios (WACHOWICZ, 2001, p.146). Outras experiências pioneiras referem-se à colônia empreendida pelo suíço João Maurício Faivre às margens do Rio Ivaí, em 1847, na tentativa de estabelecer uma comunidade agrícola sem escravidão e especulações capitalistas, e em 1852, sob a liderança de outro suíço idealista Carlos Perret Gentil, com a colônia de Superagui, atual município de Guaraqueçaba (WACHOWICZ, 2001, p.147). Outra experiência pioneira deu-se em 1859, com a criação da colônia Assungui, nos arredores do vale do Rio Ribeira, composta por brasileiros, franceses, ingleses, italianos, alemães, espanhóis e suecos (WACHOWICZ, 2001, p.149). Tais experiências, no entanto, não foram plenamente bem-sucedidas, algo que foi modificado depois do governo de Adolfo Lamenha Lins, que assumiu o governo do estado em 1875. Durante a sua gestão, fixou-se a ideia de que nenhuma colônia deveria se estabelecer longe de grandes centros consumidores e estradas carroçáveis. O problema do abastecimento da população foi atenuado com a organização, em Curitiba, do "primeiro cinturão verde organizado por imigrantes no Brasil” (WACHOWICZ, 2001, p.151), que fez surgir diversas colônias nos arredores de Curitiba ${ }^{5}$. Seu governo consolidou a imigração como uma política pública bem-sucedida e planejada que se consolidou durante o século XX, como demonstra os números do censo de 1950, que constatam o Paraná com o quarto maior contingente populacional de estrangeiros no país (76.592 indivíduos), atrás somente dos estados de São Paulo, Distrito Federal ${ }^{6}$ e Rio Grande do Sul (IANNI, 2004, p.171).

Nas próximas seções do artigo, analisaremos a influência da imigração italiana, polonesa, alemã e de outros grupos na nomeação de escolas públicas em Curitiba. O detalhamento biográfico de cada nome está presente nos apêndices deste artigo, bem como as referências bibliográficas dos levantamentos de dados e informações.

\footnotetext{
${ }^{5}$ Em 1875, foram criadas em Curitiba as colônias de Santa Cândida e Órleans. Em 1876, a capital presenciou a criação das colônias de Santo Inácio, Riviere, Dom Augusto, Dom Pedro e Lamenha (WACHOWICZ, 1976, p.12).

${ }^{6}$ Referente ao antigo estado da Guanabara.
} 


\section{Imigração e nomeação de escolas: a influência italiana}

Tendo em vista a consolidação da imigração europeia em Curitiba e o sucesso de empreendimentos coloniais após o governo Lamenha Lins, verificamos nos nomes das escolas referências a este processo. Das 161 escolas estaduais que fazem parte do município de Curitiba, 52 fazem referência a nomes e sobrenomes de personalidades ou entidades estrangeiras, ou praticamente um terço dos nomes. Destas 52 escolas, 31 fazem referência à imigração italiana, mais da metade do total de escolas.

A imigração italiana no Paraná começou a partir de 1874, a maioria com procedência de Veneto, de Vicenza de Trentino, de Abruzzo, da Basilicata e do Tirol (MARTINS, 1941, p.176). Distribuíram-se nas colônias de Assungui, e em 1875, organizados por Sabino Tripodi, colonizaram a região de Alexandra, no município de Paranaguá. Posteriormente, empreenderam a colonização em Nova Itália (Morretes), no ano de 1877, sendo estes colonos transferidos em 1878 para as colônias Alfredo Chaves (Colombo), Santa Felicidade, Senador Dantas (Água Verde), Nova Tirol (Piraquara), Murico, Zacarias, Órleans, Argelina e Rebouças, próximos aos arredores de Curitiba (MARTINS, 1941, p.71-72).

A Itália, durante as décadas de 1850 e 1860, presenciou agitações sociais e conflitos armados ocasionados pelo processo de unificação política, que, juntamente com os problemas econômicos como desemprego e aumento da pobreza, provocaram o fluxo migratório para a América (NADALIN, 2001, p.69). Dos aproximados 5 milhões de imigrantes europeus que desembarcaram no Brasil até 1974, 1 milhão e meio de imigrantes eram italianos (IANNI, 2004, p.140). Entre meados do século XIX e 1914, a imigração italiana atingiu "mais de um terço da imigração total para o Brasil" (BALHANA, 1987, p.122).

Entre os italianos e descendentes homenageados em nomes de escola, destacamos empresários e políticos como Carlos Aberto Moro, Luís Losso Filho, João Bettega, Hasdrubal Bellegard. Carlos Moro foi vereador e prefeito de Curitiba, nomeado por Bento Munhoz da Rocha Netto. Luís Losso era um industrial notável na capital. João Bettega era industrial do setor madeireiro e exportador de madeiras e produtos para outros estados do Brasil e países vizinhos. Seu filho, Lídio Paulo Bettega, foi presidentes da FIEP 
(Federação das Indústrias do Paraná) de 1958 a 1968 (OLIVEIRA, 2000, p.312). Hasdrubal Bellegard foi deputado pela ARENA durante a ditadura militar. Tais nomes homenageados são diretamente ligados à representatividade da imigração italiana na classe dominante política e econômica paranaense.

Na pesquisa de Altiva Balhana sobre a imigração italiana no Paraná, destaca-se o grande número de empresários italianos na Primeira República, a partir de um levantamento de informações obtidas através dos arquivos da Junta Comercial do Paraná entre 1890 e 1929. Nesse período, suas empresas estavam presentes em 27 dos 51 municípios do interior do estado, além de sua significativa presença em Curitiba (BALHANA, 1987, p.134). A grande participação dos imigrantes no desenvolvimento do capitalismo no Brasil deve-se às condições de classe que os mesmos já possuíam na Europa. Ricardo Costa de Oliveira, citando Warren Dean, aponta que os imigrantes, em sua maioria, "já possuíam experiências no comércio, na manufatura e detinham conhecimentos técnicos" (OLIVEIRA, 2000, p.110), ou seja, recorrentemente faziam parte da classe média urbana nos seus respectivos países de origem. Entre os homenageados nas nominações das escolas estaduais curitibanas, estão os comerciantes Ângelo Gusso e Rodolpho Zanielli.

O capital cultural desta etnia também se faz presente nas homenagens a artistas e intelectuais como Poty Lazarotto, Erasmo Piloto, João Turin e Guido Viaro. Poty Lazarotto é um dos principais expoentes dos símbolos paranistas no campo artístico, tendo os seus estudos financiados pelo interventor Manoel Ribas. João Turin foi outro artista financiado pela cúpula da classe dominante local, tendo os estudos custeados pelo presidente do estado, Vicente Machado. Por sua vez, Erasmo Piloto foi professor e notável nome da educação no Paraná.

O poder simbólico religioso também se faz presente no imaginário da imigração italiana e nas homenagens nos nomes de escolas. Religiosos ou parentes de lideranças cristãs, como João Paulo I, Santa Gemma Galgani, Domingos Zanlorenzi, Ivo Zanlorenzi, Padre Colbacchini, Dom Orione, Pio Lantéri, João Mazzarotto, Padre Cláudio Morelli. A religião tinha uma função essencial para a coesão social entre os imigrantes italianos, com apoios espirituais e materiais que possibilitavam identificação, assimilação, integração e proximidade entre os membros da comunidade (BALHANA, 1993, p.52). Em 1886, o 
padre vêneto Pietro Colbacchini mudou-se para Curitiba passando a batizar e casar colonos italianos, como um missionário para prestar assistência aos imigrantes, estabelecendo residência na Colônia Santa Felicidade em 1889, fazendo esta colônia sediar a Capelania Italiana. A maioria dos imigrantes desta colônia também era de Venêto, sendo o padre portador das mesmas tradições culturais. Padre Colbacchini mantinha correspondências com o monsenhor Scalabrini, nas quais discorria sobre as condições sociais dos colonos, denunciando precariedades (BALHANA, 1993).

Os capitais educacionais dos italianos e seus descendentes no Paraná se explicitam nas nominações de escolas dos professores Maria Heloísa Caselli, Maria Montessori, Francisco Zardo, José Busnardo, Alfredo Parodi e Laís Miqueloto.

Outros homenageados correspondem a Ângelo Trevisan, Ângelo Volpato, Natália Reginato, mãe do doador do terreno da escola, José Fresato, doador do terreno da escola, Máximo Atílio Assinelli e Paulina Pacífico Borsari.

\section{Imigração e nomeação de escolas: a influência polonesa}

O segundo grupo da imigração europeia que se destaca pela presença nos nomes e sobrenomes dos homenageados na nomeação de escolas é o polonês. Das 52 escolas analisadas, 5 possuem nomes da imigração polonesa. Até o ano de 1948, entraram no Paraná 57 mil imigrantes poloneses, ou seja, o maior contingente populacional, seguido de ucranianos (22 mil), alemães (20 mil), japoneses (15 mil) e italianos (14 mil), além de outros grupos imigrantes minoritários como franceses, austríacos, ingleses, russos, síriolibaneses, suíços, holandeses e espanhóis (WACHOWICZ, 2001, p.158). Os primeiros empreendimentos colonizadores poloneses começaram pela iniciativa do Engenheiro Sebastião Edmundo Saporski (um dos nomes homenageados) e do padre Antônio Zielinski, em 1869 (MARTINS, 1941, p.66)

A primeira colônia polonesa no Paraná foi inaugurada em 1871, chamada Pilarzinho, localizada em Curitiba (WACHOWICZ, 1976). Em dois momentos a população polonesa aumentou massivamente, nos períodos de 1890 a 1896 e de 1907 a 1914 (MARTINS, 1941, p.67). Embora os imigrantes poloneses fossem mais numerosos do que as outras nacionalidades, os mesmos não produziram uma classe industrial e 
comercial comparável à imigração alemã ou italiana, principalmente devido ao atraso das forças produtivas verificado na Polônia no século XIX, além de problemas como o analfabetismo, o frágil desenvolvimento da indústria e do comércio nas regiões de origem (OLIVEIRA, 2000, p.112). Soma-se a esses problemas, a desintegração do Estado Polonês, que teve seu território dividido e dominado pela Rússia, Prússia e Áustria desde o final do século XVIII até o término da Primeira Guerra Mundial. Esse esfacelamento de seu Estado independente é apontado por alguns estudiosos como uma das causas do atraso econômico de certas regiões da Polônia, que viviam sob intensa exploração e opressão estrangeira. (WACHOWICZ, 1981, p. 9-10). Da mesma maneira, a presença de uma fervorosa religiosidade católica apostólica romana significava a reafirmação da identidade nacional e cultural de muitos poloneses diante da dominação externa (Idem, p.93).

Uma grande colônia da imigração polonesa foi Orleans, fundada em 1875, em homenagem ao esposo da Princesa Isabel, o Conde d'Eu, Luís Felipe de Orleans. Muitos imigrantes não-poloneses abandonaram a colônia pela não adaptação, ao passo que os poloneses se estabeleceram e solicitaram auxílio ao imperador Dom Pedro II para a construção de uma igreja, a paróquia Santo Antônio (WACHOWICZ, 1976, p.15). Os poloneses possuíam traços religiosos profundos e seus empreendimentos religiosos em prol de construções de igrejas foram notáveis. Depois do Padre Ludovico Przytarski não medir esforços para a construção da Paróquia Santo Antônio entre 1878 e 1880, em 1930 a mesma foi demolida para a construção de uma outra capela, sob a liderança do padre Silvestre Kandora (que também nomeia uma escola), concluída em 1933 (WACHOWICZ, 1976, p.33). A paróquia Santo Antônio de Orleans foi dirigida por diversos padres ${ }^{7}$ imigrantes ou descendentes de poloneses, dentre eles, outro nome de escola, o Padre João Wislinski, que dirigiu a capela de 1953 a 1958.

A colônia Orleans teve como expoente educacional o professor Jerônimo Durski, que lecionou na colônia a partir do ano de 1876 (WACHOWICZ, 1976, p.40). Seu

\footnotetext{
${ }^{7}$ Além do fundador, o Padre Ludovico Przytarski (1876-1891), outros párocos da Capela Santo Antônio foram: Padre João Mientus (1898-1908), Padre Francisco Chylaszek (1908-1928), Padre Silvestre Kandora (1929-1949), Padre Inácio Zabrzeski (1949-1953), Padre João Wislinski (1953-1958), Padre Paulo Warkocz (1958-1971), Padre Viktor Paszek (1971-1973), Padre Wendelin Swierczek (1973-1975), Padre Geraldo Walenga (1975), párocos até o ano da publicação do livro de Ruy Wachowicz (1976, p.35).
} 
sucessor foi o professor João Falarz, também homenageado como nome de escola, fundador e presidente da Sociedade Agrícola Szczesc Boze (WACHOWICZ, 1976, p.73). A família também tinha a liderança do padre Henrique Osvaldo Falarz, além de Nicéforo Modesto Falarz (diretor da Escola Normal) ajudou na criação do Colégio Henrique Sienkiewicz, em 1923, em Curitiba, destinado à formação de nível médio (SWIERCZEK,1980, p. 231).

\section{Imigração e nomeação de escolas: a influência alemã}

Outro grupo que é homenageado por nomes de escolas é o que se refere à imigração alemã. Seus primeiros imigrantes estabeleceram-se no Paraná em 1829, em Rio Negro (MARTINS, 1941, p.57). O fluxo migratório de alemães se intensificou a partir do estabelecimento de colônias ao redor de Curitiba. A imigração alemã prosperou na capital, sobretudo devido às experiências comerciais anteriores e ao pertencimento à classe média urbana no país de origem, mantendo contatos com empresários e fornecedores da Europa (OLIVEIRA, 2000, p.111). Os empresários alemães eram hegemônicos em novas áreas industriais, como as "fábricas de tecidos de algodão, lã e meias, fitas e metro, fósforos, tabletes alimentícios, sabão, vidros, celulose e papel, adubos e instrumentos musicais" (OLIVEIRA, 2000, p.112). Os imigrantes adaptaram-se com facilidade ao Paraná e sua classe dominante luso-brasileira e tradicional, através de relações matrimoniais com esta (OLIVEIRA, 2000). Um exemplo de homenageado com notável influência social, política e cultural refere-se a Algacyr Munhoz Maeder, portador do título genealógico (...) (NEGRÃO, 2004, vol.6), que lhe confere a integração com a classe dominante local (possuindo parentesco com o senador Othon Mader), exercendo a docência na Universidade do Paraná e cargos no Conselho Federal de Educação, além de ocupar a prefeitura de Curitiba.

Estes imigrantes e descendentes destacam-se pelo acúmulo de capitais culturais e educacionais, como o homenageado Guido Straube. Foi professor das instituições educacionais mais importantes do Paraná, como o Ginásio Paranaense, no qual também foi professor, e a Universidade do Paraná. Straube também ocupou o cargo de Diretor Geral da Secretaria de Educação e exerceu influência cultural notável, como um dos 
precursores do positivismo no Paraná. Professoras homenageadas com sobrenome alemão referem-se a Iara Bergmann, Isolda Schimid, diretora do Colégio Estadual Júlia Wanderley, e Hildegard Sondahl, que também foi empresária do campo educacional e fundadora do colégio Bagozzi.

A imigração alemã também está relacionada à suíça, como no exemplo de outro industrial que nomeia uma escola, Gottieb Mueller. Sua indústria metalúrgica empregava em seus quadros a maioria alemã. Em sua empresa, incentivou uma caixa mútua a de auxílio social e pertencia a diversas associações de alemães em Curitiba (OLIVEIRA, 2000, p.309)

Outros grupos minoritários também que fazem parte da imigração no Paraná foram contemplados com nomes de escolas na capital. Dentre eles, os austríacos, representados pelo Deputado Olívio Belich, grupo que começou a colonizar o Paraná em 1865 (MARTINS, 1941, p.76), os húngaros, representados por Inês Borocz, que povoaram o Paraná a partir de 1971 (MARTINS, 1941, p.76), e os sírio-libaneses, representados por Aníbal Khury Netto, político de grande tradição e notórios capitais políticos e Avelino Vieira, fundador do Banco BAMERINDUS, filho de Miguel Antun, imigrante chegado ao Paraná em 1884. Após seu casamento com Cecília Bernardina Silva, em 1889, Antun passa a ter o nome de Miguel Antônio Vieira, dedicando-se ao comércio e prosperando no Norte do Paraná na região de Tomazina (OLIVEIRA, 2000, p.113).

A imigração espanhola ou a referência às ex-colônias espanholas também são contempladas nos nomes das escolas em Curitiba. Dentre os homenageados, tem-se professores como Prieto Martinez, a poeta e escritora chilena Gabriela Mistral, além do país Uruguai e a educadora Pilar Maturana. Outros descendentes de nacionalidades diversas referem-se a Senhorinha de Moraes Sarmento e Ernani Vidal.

\section{Considerações Finais}

As reproduções dos capitais sociais no campo educacional estão relacionadas à nominação dos patronos das escolas. Vinculada a esta dinâmica, está a nomeação de 
escolas com homenageados que possuem sobrenomes estrangeiros em Curitiba, historicamente associada a influência imigrante na sua identidade. $\mathrm{O}$ ato de nomear possui significado social e reflete a ideologia que permeia algumas formas de dominação e reprodução das desigualdades sociais.

Tal reprodução estava aliada a teorias eugênicas, que ganharam força no final do século XIX e início do século XX, com o discurso colonizador eurocêntrico, e os modelos de sucesso nacional que sempre remetiam aos países do Hemisfério Norte (em especial os Estados Unidos da América). Discursos que associavam a miscigenação, o negro, o mulato e o indígena como fontes de seculares mazelas sociais exerceram grande influência nas políticas de imigração empreendidas pelo Estado brasileiro e aclamada no Paraná, em especial na região do litoral e na capital.

Assinalamos a influência exercida pelos campos econômicos, políticos e sociais para a promoção da homenagem aos agentes que nomeiam as escolas que possuem sobrenome associados a imigração europeia. Isso possui um significado simbólico que afirma a reprodução das desigualdades sociais, uma vez que, implicitamente, a afirmação ao "elemento branco" através das homenagens em nomes de escolas está associada a glorificação dos "traços culturais" do "europeísmo" e do "ocidentalismo" (RODRIGUES, 1965, p.118). A desvalorização do elemento nacional, a marginalização do povo e a exclusão de amplos setores da sociedade brasileira são características que afirmam a essência do elitismo da classe dominante brasileira.

Nessa linha, Jessé Souza ressalta que a própria Ciência pode colaborar para a manutenção desses valores colonizados que, na verdade, nada mais fazem do que justificar todo um processo de exploração material, através da dominação simbólica. Ao criticar clássicos da Sociologia e da Historiografia brasileira, Souza demonstra o quanto uma série de conceitos vistos como científicos colaboraram para séculos de construção de um pensamento submisso diante do resto do mundo, o qual acaba por sedimentar a imagem negativa que a maioria dos brasileiros tem do seu próprio povo. Tendo como referência o protestante asséptico da América do Norte, esse conjunto de valores é incutido na maioria da população desde a mais tenra infância, de maneira contínua e sistemática, até que as desigualdades, a exploração, a miséria e a violência, em especial aquelas que existem entre as camadas mais pobres da população, sejam naturalizadas ao 
ponto de explicarmos sua origem através dos estereótipos do brasileiro preguiçoso, corrupto, irresponsável e irracional (SOUZA, 2015) (Idem, 2017).

Se somarmos as ideias ligadas a eugenia, que impulsionaram muitas das políticas imigratórias para o Brasil, com essa autoimagem construída propositalmente do povo brasileiro como inferior e corrupto, podemos indicar uma linha interpretativa a respeito da escolha da nomenclatura das escolas em diversas partes do Brasil, principalmente no Sul do país. Em Curitiba, praticamente um terço das escolas regulares do ensino estadual possui nomes de estrangeiros. Isso significa que a definição desses homenageados também pode ter seguido a lógica de valorização das etnias estrangeiras, uma vez que não se verifica a mesma frequência dessa escolha para nomes que representem membros da comunidade negra, indígena, mestiça, ou mesmo de brancos pertencentes às camadas mais pobres da população.

\section{Referências Bibliográficas}

BALHANA, Altiva Pilatti. "Italianos no Paraná". In: DE BONI, Luis (org.). A presença italiana no Brasil. Porto Alegre: Escola Superior de Teologia e Fondazione Giovanni Agnelli, 1987. BALHANA, Altiva Pilatti. Religião e imigração. Revista do Círculo de Estudos Bandeirantes. Curitiba, n.7, jul 1993. p. 51-60. Disponível em: <http://www.pucpr.br/circuloestudos/revistas.php>. Acesso em: 20/07/2018.

BOURDIEU, Pierre. "O campo político". Revista Brasileira de Ciência Política, n.5, Brasília, , p.193-216, jan./jul. 2011.

DICK, Maria Vicentina de Paula do Amaral. A Motivação Toponímica: princípios teóricos e modelos taxionômicos. São Paulo, FFLCH/USP, 1990.

HOFBAUER, Andreas. "Branqueamento e democracia racial: sobre as entranhas do racismo no Brasil". 2011. Disponível em: $<$ https://andreashofbauer.files.wordpress.com/2011/08/branqueamento-e-democraciaracial_finalc3adssima_2011.pdf $>$. Acesso em: 27/06/2018. 
IANNI, Octavio. Tendências do pensamento brasileiro. Tempo Social - Rev. Sociol. USP, S. Paulo, 12(2): 55-74, novembro de 2000.

IANNI, Octavio. Estado e capitalismo: estrutura social e industrialização no Brasil. São Paulo: Brasiliense, 2004.

MACIEL, Maria Eunice de S. “A eugenia no Brasil”. Anos 90, Porto Alegre, UFRGS, v.7, n.11, p. 121-143, 1999.

MARTINS, Romário. Quantos somos e quem somos: dados para a história e a estatística do povoamento do Paraná. Curitiba. Empr. Graf. Paranaense, 1941.

NADALIN, Sérgio Odilon. Paraná: Ocupação do Território, População e Migrações. Curitiba: Secretaria de Estado da Educação do Paraná, 2001.

NORA, Pierre. Entre memória e história. A problemática dos lugares. Projeto História. Revista do Programa de estudos pós-graduados de História. São Paulo (10). Dezembro de 1993.

OLIVEIRA, Márcio. “A inesperada descoberta de Otávio Ianni sobre preconceito contra descendentes de imigrantes poloneses em Curitiba". Soc. Estado, Brasília, UnB, v. 30, n. 3, p. 799-817, 2015.

OLIVEIRA, Ricardo Costa de. O silêncio das genealogias: classe dominante e Estado no Paraná (1853-1930). Tese de Doutorado, Universidade Estadual de Campinas, Campinas, SP, Brasil, 2000.

RODRIGUES, José Honório. Conciliação e Reforma no Brasil: um desafio históricopolítico. Rio de Janeiro: Editora Civilização Brasileira, 1965.

SANTOS, Luiz Eduardo Neves dos. Toponímia, poder e identidade: uma abordagem acerca dos logradouros centrais em São Luís, Maranhão. Geo UERJ, 28, p. 171-195, 2016.

SOUZA, Jessé. A elite do atraso - da escravidão à lava-jato. São Paulo: LeYa, 2017.

SOUZA, Jessé. A tolice da inteligência brasileira - ou como o país se deixa manipular pela elite. São Paulo: LeYa, 2015.

SWIERCZEK, Wendelin. A seara do semeador. Curitiba: Vicentina, 1980.

WACHOWICZ, Ruy Christovam. O camponês polonês no Brasil. Curitiba: Fundação Cultural de Curitiba, 1981.

Orleans: um século de subsistência. Curitiba: Paiol, 1976. 
História do Paraná. Curitiba: Imprensa Oficial, 2001.

APÊNDICE 1: IMIGRAÇÃO ITALIANA NOS NOMES DE ESCOLAS EM CURITIBA

\begin{tabular}{|c|c|c|c|c|c|c|}
\hline $\begin{array}{l}\text { Nome } \\
\text { completo/ } \\
\text { Procedência } \\
\text { do } \\
\text { Sobrenome/ } \\
\text { Bairro }\end{array}$ & Profissão & Atuação & $\begin{array}{l}\text { Ano } \\
\text { de } \\
\text { Fund } \\
\text { ação } \\
\text { Escol } \\
\text { a }\end{array}$ & $\begin{array}{l}\text { Ano } \\
\text { de } \\
\text { Nome } \\
\text { ação }\end{array}$ & Capitais Políticos & Capitais Educacionais \\
\hline $\begin{array}{l}\text { Colégio } \\
\text { Estadual } \\
\text { Amâncio } \\
\text { Moro/ } \\
\text { Itália/ } \\
\text { Jardim Social }\end{array}$ & $\begin{array}{l}\text { Industrial, } \\
\text { Comerciante, } \\
\text { foi sócio da } \\
\text { firma } \\
\text { Madereira } \\
\text { Moro \&Cia } \\
\text { Ltda. }\end{array}$ & $\begin{array}{l}\text { Nasceu em Curitiba, } \\
\text { 1908. Vereador em } \\
\text { Curitiba, PTB, 1947- } \\
\text { 1951; Presidente da } \\
\text { Federação Paranaense } \\
\text { de Futebol de } 1948 \text { a } \\
\text { 1950 e do Coritiba } \\
\text { Futebol Clube }\end{array}$ & 1968 & 1970 & $\begin{array}{l}\text { Prefeito de Curitiba de } \\
\text { janeiro a julho de 1951, pelo } \\
\text { PTB, nomeado pelo então } \\
\text { governador do estado Bento } \\
\text { Munhoz da Rocha Netto. } \\
\text { Seu filho, Carlos Alberto } \\
\text { Moro, foi Vereador em } \\
\text { Curitiba, pelo PTB, de 1960- } \\
\text { 1963; Delegado Regional do } \\
\text { Instituto de Aposentados e } \\
\text { Pensões dos Industriários; } \\
\text { Secretário do Trabalho e } \\
\text { Assistência Social no } \\
\text { governo Paulo Pimentel, no } \\
\text { qual também ocupou a pasta } \\
\text { da Educação (ALMEIDA, } \\
\text { 1968, p.210). }\end{array}$ & \\
\hline $\begin{array}{l}\text { Centro } \\
\text { Estadual de } \\
\text { Educação } \\
\text { Básica de } \\
\text { Jovens e } \\
\text { Adultos Poty } \\
\text { Lazzaroto } \\
\text { Itália } \\
\text { Centro }\end{array}$ & $\begin{array}{l}\text { Professor, } \\
\text { Desenhista, } \\
\text { ilustrador, } \\
\text { ceramista e } \\
\text { muralista }\end{array}$ & $\begin{array}{l}\text { Filho de Pai ferroviário } \\
\text { e mãe proprietária de } \\
\text { um restaurante } \\
\text { frequentado por } \\
\text { intelectuais, suas obras } \\
\text { estão presentes em } \\
\text { várias cidades do Brasil } \\
\text { e do exterior. Formado } \\
\text { pela Escola Nacional de } \\
\text { Belas Artes, Rio de } \\
\text { Janeiro. Fundador da } \\
\text { Escola Livre de Artes } \\
\text { Plásticas. Estudou } \\
\text { Litografia em Paris. }\end{array}$ & 1980 & 1998 & $\begin{array}{l}\text { O interventor Manoel Ribas } \\
\text { custeou seus estudos no Rio } \\
\text { de Janeiro }\end{array}$ & $\begin{array}{l}\text { Ilustrador de livros escritos } \\
\text { por autores como Jorge } \\
\text { Amado, Graciliano Ramos, } \\
\text { Euclides da Cunha e Dalton } \\
\text { Trevisan, entre outros. } \\
\text { Colaborador da revista } \\
\text { Joaquim }\end{array}$ \\
\hline $\begin{array}{l}\text { Instituto de } \\
\text { Educação } \\
\text { Professor } \\
\text { Erasmo } \\
\text { Pilloto } \\
\text { Itália } \\
\text { Centro } \\
\end{array}$ & $\begin{array}{l}\text { Professor e } \\
\text { militante do } \\
\text { movimento } \\
\text { pela Escola } \\
\text { Nova no } \\
\text { Paraná }\end{array}$ & $\begin{array}{l}\text { Filho de pai telegrafista } \\
\text { e mãe professora } \\
\text { primária. Descendente } \\
\text { de italianos }\end{array}$ & 1876 & 1992 & & $\begin{array}{l}\text { Fundador do Centro de } \\
\text { Cultura Pedagógica. }\end{array}$ \\
\hline $\begin{array}{l}\text { Colégio } \\
\text { Estadual } \\
\text { Ângelo Gusso } \\
\text { Itália } \\
\text { Boa Vista } \\
\end{array}$ & $\begin{array}{l}\text { Entalhador de } \\
\text { madeira e } \\
\text { colaborador de } \\
\text { assuntos } \\
\text { comunitários }\end{array}$ & $\begin{array}{l}\text { Descendente de } \\
\text { italianos, proprietário } \\
\text { de uma fábrica de } \\
\text { móveis entalhados }\end{array}$ & 1960 & 1979 & & \\
\hline $\begin{array}{l}\text { Colégio } \\
\text { Estadual Papa } \\
\text { João Paulo I } \\
\text { Itália } \\
\text { Boa Vista }\end{array}$ & Padre & $\begin{array}{l}\text { Albino Luciani nasceu } \\
\text { em Canale d'Agordo, } \\
\text { Itália, } 1912\end{array}$ & & 1978 & $\begin{array}{l}\text { Patriarca de Veneza e Papa } \\
\text { da Igreja Católica } \\
\text { Apostólica Romana }\end{array}$ & \\
\hline $\begin{array}{l}\text { Escola } \\
\text { Estadual } \\
\text { Professora } \\
\text { Maria Heloísa } \\
\text { Caselli } \\
\text { Itália } \\
\text { Pilarzinho } \\
\end{array}$ & $\begin{array}{l}\text { Professora } \\
\text { nascida em } \\
\text { São João do } \\
\text { Triunfo }\end{array}$ & & 1968 & 1991 & & \\
\hline $\begin{array}{l}\text { Colégio } \\
\text { Estadual } \\
\text { Maria } \\
\text { Montessori } \\
\text { Itália } \\
\text { Tingui }\end{array}$ & $\begin{array}{l}\text { Médica } \\
\text { nascida na } \\
\text { Itália }\end{array}$ & $\begin{array}{l}\text { Pedagoga fundadora de } \\
\text { um novo método } \\
\text { pedagógico, cujos eixos } \\
\text { centrais são a } \\
\text { Individualidade, a } \\
\text { atividade e a liberdade } \\
\text { do aluno, entendido }\end{array}$ & 1952 & 1952 & & $\begin{array}{l}\text { Autora de diversas obras } \\
\text { sobre pedagogia, como O } \\
\text { segredo da Infância, (1936). } \\
\text { Mente Absorvente (1949); } \\
\text { Formação do Homem } \\
\text { (1949); } \\
\text { Em Família, (1951); }\end{array}$ \\
\hline
\end{tabular}


Revista NEP, Núcleo de Estudos Paranaenses, Curitiba, v.4, n.2, dez. 2018

\begin{tabular}{|c|c|c|c|c|c|c|}
\hline & & $\begin{array}{l}\text { como sujeito e objeto } \\
\text { do processo de ensino- } \\
\text { aprendizagem }\end{array}$ & & & & $\begin{array}{l}\text { Pedagogia Científica (1965); } \\
\text { A Criança, com Luíz } \\
\text { Horácio da Matta; } \\
\text { Educação e a Paz; } \\
\text { Para Educar o Potencial } \\
\text { Humano; }\end{array}$ \\
\hline $\begin{array}{l}\text { Colégio } \\
\text { Estadual } \\
\text { Santa Gemma } \\
\text { Galgani } \\
\text { Itália } \\
\text { Abranches } \\
\end{array}$ & $\begin{array}{l}\text { Italiana, Santa } \\
\text { padroeira do } \\
\text { Bairro } \\
\text { Barreirinha }\end{array}$ & & 1978 & 1978 & & \\
\hline $\begin{array}{l}\text { Centro } \\
\text { Estadual de } \\
\text { Educação } \\
\text { Básica de } \\
\text { Jovens e } \\
\text { Adultos } \\
\text { Doutor Luís } \\
\text { Losso Filho } \\
\text { Itália } \\
\text { Atuba }\end{array}$ & $\begin{array}{l}\text { Empresário e } \\
\text { proprietário do } \\
\text { escritório de } \\
\text { Direito Losso, } \\
\text { em Curitiba }\end{array}$ & $\begin{array}{l}\text { Proprietário da Casa } \\
\text { Losso e a Indústria de } \\
\text { Bebidas de Irati. } \\
\text { Fazendeiro em } \\
\text { Guarapuava e um dos } \\
\text { fundadores de Campo } \\
\text { Mourão }\end{array}$ & & & $\begin{array}{l}\text { Assessor técnico da } \\
\text { Assembleia Legislativa do } \\
\text { Paraná em 1962, fundador } \\
\text { da ARENA, deputado } \\
\text { federal pela ARENA de } \\
\text { 1973 a 1975. Seu filho, Igo } \\
\text { Losso, foi deputado federal } \\
\text { da ARENA pelo Paraná } \\
\text { entre } 1975 \text { e } 1983 .\end{array}$ & $\begin{array}{l}\text { Formado História e } \\
\text { Geografia na Faculdade } \\
\text { Católica de Filosofia, } \\
\text { Ciências e Letras do Paraná, } \\
\text { em 1950, e em Direito na } \\
\text { Universidade do Paraná em } \\
\text { 1953, professor do ensino } \\
\text { secundário }\end{array}$ \\
\hline $\begin{array}{l}\text { Colégio } \\
\text { Estadual } \\
\text { Domingos } \\
\text { Zanlorenzi } \\
\text { Itália } \\
\text { Cidade } \\
\text { Industrial }\end{array}$ & & $\begin{array}{l}\text { Imigrante italiano, } \\
\text { primo do Monsenhor } \\
\text { Ivo Zanlorenzi. A } \\
\text { família Zanlorenzi } \\
\text { também é proprietária } \\
\text { de uma vinícola em } \\
\text { Campo Largo }\end{array}$ & 1976 & 1976 & & \\
\hline $\begin{array}{l}\text { Escola } \\
\text { Estadual } \\
\text { Monsenhor } \\
\text { Ivo } \\
\text { Zanlorenzi } \\
\text { Itália } \\
\text { Campo } \\
\text { Comprido }\end{array}$ & Monsenhor & $\begin{array}{l}\text { Imigrante italiano, } \\
\text { dono do primeiro } \\
\text { armazém de secos e } \\
\text { molhados em Campo } \\
\text { Comprido. }\end{array}$ & 1959 & 1984 & & \\
\hline $\begin{array}{l}\text { Escola } \\
\text { Estadual } \\
\text { Angelo } \\
\text { Trevisan } \\
\text { Itália } \\
\text { Santa } \\
\text { Felicidade }\end{array}$ & & $\begin{array}{l}\text { Secretário do } \\
\text { Embaixador veneziano } \\
\text { em Castela }\end{array}$ & 1950 & 1970 & & \\
\hline $\begin{array}{l}\text { Colégio } \\
\text { Estadual } \\
\text { Ângelo } \\
\text { Volpato } \\
\text { Itália } \\
\text { Santa } \\
\text { Felicidade }\end{array}$ & & & 1961 & 1961 & & \\
\hline $\begin{array}{l}\text { Escola } \\
\text { Estadual } \\
\text { Padre } \\
\text { Colbacchini } \\
\text { Itália } \\
\text { Butiatuvinha }\end{array}$ & Padre & $\begin{array}{l}\text { Imigrante italiano e } \\
\text { padre em Santa } \\
\text { Felicidade. Vêteto, } \\
\text { descendente de uma } \\
\text { família de fundidores } \\
\text { de sinos. }\end{array}$ & 1967 & 1969 & & $\begin{array}{l}\text { Em } 1884 \text { mudou-se para São } \\
\text { Paulo após impressionar-se } \\
\text { com cartas de imigrantes } \\
\text { italianos no Brasil, } \\
\text { estabelecendo residência em } \\
\text { Santa Felicidade a partir de } \\
\text { 1889. (BALHANA, 1993) }\end{array}$ \\
\hline $\begin{array}{l}\text { Colégio } \\
\text { Estadual } \\
\text { Professor } \\
\text { Francisco } \\
\text { Zardo } \\
\text { Itália } \\
\text { Butiatuvinha } \\
\end{array}$ & $\begin{array}{l}\text { Professor } \\
\text { primário }\end{array}$ & $\begin{array}{l}\text { Imigrante italiano } \\
\text { nascido em Vêneto }\end{array}$ & 1943 & 1975 & & \\
\hline $\begin{array}{l}\text { Colégio } \\
\text { Estadual João } \\
\text { Turin } \\
\text { Itália } \\
\text { Rebouças }\end{array}$ & $\begin{array}{l}\text { Escultor, } \\
\text { pintor e } \\
\text { professor }\end{array}$ & $\begin{array}{l}\text { Descendente de } \\
\text { imigrantes italianos }\end{array}$ & 1969 & 2008 & $\begin{array}{l}\text { Sua bolsa em Bruxelas foi } \\
\text { patrocinada pelo presidente } \\
\text { do Paraná Vicente Machado. } \\
\text { Precursor, juntamente com } \\
\text { juntamente com Lange de } \\
\text { Morretes e Zaco Paraná, do } \\
\text { movimento Paranista }\end{array}$ & $\begin{array}{l}\text { Estudou na Escola de Belas } \\
\text { Artes de Bruxelas }\end{array}$ \\
\hline $\begin{array}{l}\text { Colégio } \\
\text { Estadual José } \\
\text { Busnardo }\end{array}$ & $\begin{array}{l}\text { Professor } \\
\text { Normalista }\end{array}$ & $\begin{array}{l}\text { Italiano nascido em } \\
1888\end{array}$ & 1955 & 1959 & $\begin{array}{l}\text { Inspetor de Ensino de } \\
\text { Curitiba desde } 1924 . \\
\text { Delegado e Técnico de }\end{array}$ & $\begin{array}{l}\text { Estudou na Escola Normal } \\
\text { de Curitiba }\end{array}$ \\
\hline
\end{tabular}


Revista NEP, Núcleo de Estudos Paranaenses, Curitiba, v.4, n.2, dez. 2018

\begin{tabular}{|c|c|c|c|c|c|c|}
\hline $\begin{array}{l}\text { Itália } \\
\text { Fanny }\end{array}$ & & & & & $\begin{array}{l}\text { Ensino da Secretaria de } \\
\text { Educação }\end{array}$ & \\
\hline $\begin{array}{l}\text { Escola } \\
\text { Estadual Dom } \\
\text { Orione } \\
\text { Itália } \\
\text { Santa Quitéria }\end{array}$ & $\begin{array}{l}\text { Dom Luigi } \\
\text { Orione foi um } \\
\text { sacerdote } \\
\text { católico e } \\
\text { proclamado } \\
\text { santo pelo } \\
\text { Papa João } \\
\text { Paulo II em } \\
2004\end{array}$ & $\begin{array}{l}\text { Nasceu em } \\
\text { Pontecurone. } \\
\text { Alexandria, Itália, no } \\
\text { ano de } 1872\end{array}$ & 1967 & 1967 & $\begin{array}{l}\text { Fundador da Congregação } \\
\text { da "Pequena Obra da Divina } \\
\text { Providência }\end{array}$ & $\begin{array}{l}\text { Formado em Filosofia e } \\
\text { Teologia }\end{array}$ \\
\hline $\begin{array}{l}\text { Colégio } \\
\text { Estadual João } \\
\text { Bettega } \\
\text { Itália } \\
\text { Novo Mundo }\end{array}$ & $\begin{array}{l}\text { Empresário, } \\
\text { industrial, } \\
\text { fundador de } \\
\text { serrarias, } \\
\text { exportador } \\
\text { madeireiro }\end{array}$ & $\begin{array}{l}\text { Nasceu na Província de } \\
\text { Trento, na Itália, em } \\
1864 \text { Proprietário da } \\
\text { fazenda Rio Grande, no } \\
\text { atual Município de São } \\
\text { José dos Pinhais } \\
\text { Fundou diversas } \\
\text { serarias, como a } \\
\text { Colônia Nova } \\
\text { Tyril, em Piraquara, } \\
\text { além de outras } \\
\text { localizadas no Rio da } \\
\text { Várzea, Pangaré, São } \\
\text { João do Triunfo, } \\
\text { Rancho das Táboas, } \\
\text { Faxinal do Silva, } \\
\text { Campo do Tenente e } \\
\text { Porto Amazonas. } \\
\text { Primeiro a instalar } \\
\text { telefone que ligava } \\
\text { Curitiba a Fazenda Rio } \\
\text { Grande e o segundo a } \\
\text { possuir um carro em } \\
\text { Curitiba. Primeiro } \\
\text { exportador de pinho } \\
\text { nacional para a } \\
\text { Argentina }\end{array}$ & 1978 & 1978 & $\begin{array}{l}\text { Contador de Ildefonso } \\
\text { Pereira Correia, o Barão do } \\
\text { Serro Azul. Atualmente, a } \\
\text { família Bettega conta com } \\
\text { notáveis representantes } \\
\text { como o desembargador do } \\
\text { Tribunal de Justiça, Renato } \\
\text { Braga Bettega, além de } \\
\text { vários comerciantes e } \\
\text { empresários. }\end{array}$ & \\
\hline $\begin{array}{l}\text { Centro de } \\
\text { Capacitação } \\
\text { em Artes } \\
\text { Guido Viaro } \\
\text { Itália } \\
\text { Capão da } \\
\text { Imbuia }\end{array}$ & $\begin{array}{l}\text { Desenhista, } \\
\text { gravurista, } \\
\text { escultor }\end{array}$ & $\begin{array}{l}\text { Nasceu em } 1897 \text { em } \\
\text { Badia Polesine, na } \\
\text { Itália. Introdutor da } \\
\text { pintura moderna no } \\
\text { Paraná. Conheceu a } \\
\text { arte de Veneza, } \\
\text { Florença, Milão, Roma } \\
\text { e Paris e se dirigiu ao } \\
\text { Brasil, onde morou no } \\
\text { Rio de Janeiro, São } \\
\text { Paulo e Curitiba, onde } \\
\text { fixou residência em } \\
1929\end{array}$ & 1886 & 1992 & $\begin{array}{l}\text { Ilustrador da Revista } \\
\text { Joaquim, ao lado de Potty } \\
\text { Lazarotto }\end{array}$ & $\begin{array}{l}\text { Desde 1948, foi Foi } \\
\text { professor da Escola de } \\
\text { Música e Belas Artes do } \\
\text { Paraná (EMBAP). Amigo } \\
\text { dos artistas Theodoro de } \\
\text { Bona e Alfred Andersen }\end{array}$ \\
\hline $\begin{array}{l}\text { Colégio } \\
\text { Estadual } \\
\text { Natália } \\
\text { Reginato } \\
\text { Itália } \\
\text { Cajuru } \\
\end{array}$ & & $\begin{array}{l}\text { Descendência italiana, } \\
\text { mãe do proprietário do } \\
\text { terreno doado à } \\
\text { Prefeitura de Curitiba, } \\
\text { o senhor Frederico } \\
\text { Reginato }\end{array}$ & 1960 & 1983 & & \\
\hline $\begin{array}{l}\text { Colégio } \\
\text { Estadual } \\
\text { Alfredo } \\
\text { Parodi } \\
\text { Itália } \\
\text { Uberaba }\end{array}$ & Educador & $\begin{array}{l}\text { Fundou, em 1917, o } \\
\text { Colégio Iguassu }\end{array}$ & & & & \\
\hline $\begin{array}{l}\text { Colégio } \\
\text { Estadual } \\
\text { Professor } \\
\text { Máximo } \\
\text { Atílio Asinelli } \\
\text { Itália } \\
\text { Uberaba }\end{array}$ & & & 1974 & 1991 & & \\
\hline $\begin{array}{l}\text { Colégio } \\
\text { Estadual Pio } \\
\text { Lanteri } \\
\text { Itália } \\
\text { Guabirotuba } \\
\end{array}$ & $\begin{array}{l}\text { Pio Bruno } \\
\text { Lanteri era } \\
\text { formador de } \\
\text { laicos, } \\
\text { religiosos } \\
\end{array}$ & $\begin{array}{l}\text { Nasceu em Cúneo, } \\
\text { Itália, } 1759\end{array}$ & 1969 & 1978 & & \\
\hline $\begin{array}{l}\text { Colégio } \\
\text { Estadual João } \\
\text { Mazzarotto } \\
\text { Itália }\end{array}$ & & $\begin{array}{l}\text { Membro da família } \\
\text { Mazzarotto, de } \\
\text { descendência italiana, } \\
\text { uma das principais }\end{array}$ & 1967 & 1967 & $\begin{array}{l}\text { Suplente de deputado } \\
\text { estadual pelo PDC, eleições } \\
\text { de } 1955 \text {. Parentesco com } \\
\text { Dom Jerônimo Mazzarotto, }\end{array}$ & \\
\hline
\end{tabular}




\begin{tabular}{|c|c|c|c|c|c|c|}
\hline Capão Raso & & $\begin{array}{l}\text { colonizadoras de Santa } \\
\text { Felicidade }\end{array}$ & & & $\begin{array}{l}\text { padre, bispo de Curitiba e } \\
\text { professor } \\
\text { universitário, fundador e } \\
\text { reitor da Pontifícia } \\
\text { Universidade } \\
\text { Católica do Paraná entre } \\
1959 \text { e } 1973 \text { e Dom } \\
\text { Antonio Mazzarotto, bispo } \\
\text { de Ponta Grossa } \\
\end{array}$ & \\
\hline $\begin{array}{l}\text { Colégio } \\
\text { Estadual } \\
\text { Padre Cláudio } \\
\text { Morelli } \\
\text { Itália } \\
\text { Umbará } \\
\end{array}$ & Padre & $\begin{array}{l}\text { Fundador da primeira } \\
\text { escola em Umbará, } \\
\text { bairro rural composto } \\
\text { de imigrantes italianos } \\
\text { e poloneses }\end{array}$ & 1953 & 1967 & $\begin{array}{l}\text { O colégio surgiu como um } \\
\text { anexo à igreja e a casa das } \\
\text { Irmãs da Congregação } \\
\text { Filhas de Nossa Senhora da } \\
\text { Misericórdia, tornando-se } \\
\text { estadual em } 1972\end{array}$ & \\
\hline $\begin{array}{l}\text { Colégio } \\
\text { Estadual } \\
\text { Hasdrubal } \\
\text { Bellegard } \\
\text { Itália } \\
\text { Sítio Cercado }\end{array}$ & $\begin{array}{l}\text { Agrônomo e } \\
\text { Economista }\end{array}$ & $\begin{array}{l}\text { Nasceu em Paranaguá, } \\
1896\end{array}$ & 1978 & 1989 & $\begin{array}{l}\text { Diretor do Departamento } \\
\text { Econômico da Federação } \\
\text { das Indústrias do Paraná e } \\
\text { como Presidente da } \\
\text { Distribuidora Cummis } \\
\text { Diesel do Paraná. Deputado }\end{array}$ & \\
\hline $\begin{array}{l}\text { Centro } \\
\text { Estadual de } \\
\text { Educação } \\
\text { Básica de } \\
\text { Jovens e } \\
\text { Adultos } \\
\text { Professora } \\
\text { Laís } \\
\text { Miqueloto } \\
\text { Itália } \\
\text { Cidade } \\
\text { Industrial } \\
\end{array}$ & Professora & & & & & \\
\hline $\begin{array}{l}\text { Colégio } \\
\text { Estadual José } \\
\text { Fressato } \\
\text { Itália } \\
\text { Campo } \\
\text { Comprido } \\
\end{array}$ & $\begin{array}{l}\text { Pioneiro da } \\
\text { região do } \\
\text { Capão da } \\
\text { Imbuia }\end{array}$ & $\begin{array}{l}\text { Doador do terreno da } \\
\text { escola }\end{array}$ & 1982 & 1991 & & \\
\hline $\begin{array}{l}\text { Colégio } \\
\text { Estadual } \\
\text { Rodolpho } \\
\text { Zaninelli } \\
\text { Itália } \\
\text { Cidade } \\
\text { Industrial }\end{array}$ & & $\begin{array}{l}\text { Curitibano que se } \\
\text { destacou por fabricar } \\
\text { sapatos para deficientes } \\
\text { físicos }\end{array}$ & 1991 & 1997 & & \\
\hline
\end{tabular}

Fonte: Autoras.

\section{APÊNDICE 2: IMIGRAÇÃO POLONESA}

\begin{tabular}{|l|l|l|l|l|l|l|}
\hline $\begin{array}{l}\text { Nome } \\
\text { completo/ } \\
\text { Procedência } \\
\text { do }\end{array}$ & Profissão & Atuação & $\begin{array}{l}\text { Ano } \\
\text { de } \\
\text { Sobrenome/ } \\
\text { Bairro }\end{array}$ & $\begin{array}{l}\text { Ano } \\
\text { de } \\
\text { daçã } \\
\text { o } \\
\text { escomão } \\
\text { la }\end{array}$ & $\begin{array}{l}\text { Capitais Políticos } \\
\text { Capitais Educacionais }\end{array}$ & \\
\hline $\begin{array}{l}\text { Escola } \\
\text { Estadual } \\
\begin{array}{l}\text { Padre João } \\
\text { Wislinski }\end{array}\end{array}$ & $\begin{array}{l}\text { Padre, } \\
\text { nolônia } \\
\text { Santânia, } \\
\text { Cândida }\end{array}$ & $\begin{array}{l}\text { Concluiu a } \\
\text { construção da } \\
\text { paróquia do Santa } \\
\text { Cândida. } \\
\text { Comandou a } \\
\text { paróquia do Orleans } \\
\text { entre 1953 e 1958. }\end{array}$ & 1989 & 1989 & & \\
\hline $\begin{array}{l}\text { Colégio } \\
\text { Estadual } \\
\text { Sebastião } \\
\text { Saporski } \\
\text { Polônia } \\
\text { Taboão }\end{array}$ & $\begin{array}{l}\text { Engenheiro } \\
\text { agrimensor e } \\
\text { ativista da } \\
\text { diáspora } \\
\text { polonesa }\end{array}$ & $\begin{array}{l}\text { Erecursor da vinda } \\
\text { dos primeiros } \\
\text { grupos de imigrantes } \\
\text { poloneses ao Paraná } \\
\text { Auxiliar na } \\
\text { construção da }\end{array}$ & 1980 & 1998 & $\begin{array}{l}\text { O interventor Manoel } \\
\text { Ribas custeou seus } \\
\text { estudos no Rio de } \\
\text { Janeiro } \\
\text { Engenheiro auxiliar da } \\
\text { prefeitura de Curitiba, } \\
\text { Chefe da Comissão }\end{array}$ & $\begin{array}{l}\text { Ilustrador de livros } \\
\text { escritos por autores } \\
\text { como Jorge Amado, } \\
\text { Graciliano Ramos, } \\
\text { Euclides da Cunha e } \\
\text { Dalton Trevisan, entre } \\
\text { outros. Colaborador da } \\
\text { revista Joaquim }\end{array}$ \\
\hline
\end{tabular}


Revista NEP, Núcleo de Estudos Paranaenses, Curitiba, v.4, n.2, dez. 2018

\begin{tabular}{|c|c|c|c|c|c|c|}
\hline & & $\begin{array}{l}\text { ferrovia Curitiba- } \\
\text { Paranaguá. }\end{array}$ & & & $\begin{array}{l}\text { Colonizadora e } \\
\text { Comissário de terras. } \\
\text { Eleito deputado estadual } \\
\text { para a legislatura de } \\
1913 .\end{array}$ & $\begin{array}{l}\text { Em } 1890 \text { formou a } \\
\text { primeira Sociedade } \\
\text { polonesa "Tadeusz } \\
\text { kosciuszko" e ao lado de } \\
\text { C. Szulc fundou o jornal } \\
\text { "Gazeta Polonesa no } \\
\text { Brasil" }\end{array}$ \\
\hline $\begin{array}{l}\text { Colégio } \\
\text { Estadual } \\
\text { Paulo } \\
\text { Leminski } \\
\text { Polônia } \\
\text { Tarumã }\end{array}$ & $\begin{array}{l}\text { Poeta, } \\
\text { escritor, } \\
\text { tradutor e } \\
\text { professor }\end{array}$ & $\begin{array}{l}\text { Filho de Paulo } \\
\text { Leminski, militar de } \\
\text { origem polonesa, e } \\
\text { Áurea Pereira } \\
\text { Mendes, de } \\
\text { descendência } \\
\text { africana. }\end{array}$ & 1993 & 1994 & & $\begin{array}{l}\text { Autor de diversas obras, } \\
\text { entre elas Catatau ; Não } \\
\text { Fosse Isso e Era } \\
\text { Menos/Não Fosse } \\
\text { Tanto/e Era Quase; } \\
\text { Caprichos e Relaxos ; } \\
\text { Agora é Que São Elas ; } \\
\text { Anseios Crípticos } \\
\text { Distraídos Venceremos; } \\
\text { Guerra Dentro da Gente; } \\
\text { La Vie Em Close }\end{array}$ \\
\hline $\begin{array}{l}\text { Colégio } \\
\text { Estadual } \\
\text { Padre } \\
\text { Silvestre } \\
\text { Kandora } \\
\text { Polônia } \\
\text { São Braz }\end{array}$ & Padre & $\begin{array}{l}\text { Padre na Paróquia } \\
\text { Órleans, concluiu a } \\
\text { construção da Igreja } \\
\text { de Santo Antonio } \\
\text { em } 1932 .\end{array}$ & 1979 & 1979 & & \\
\hline $\begin{array}{l}\text { Colégio } \\
\text { Estadual } \\
\text { Segismundo } \\
\text { Falarz } \\
\text { Polônia } \\
\text { Hauer }\end{array}$ & Professor & $\begin{array}{l}\text { Descendente de } \\
\text { poloneses, filho de } \\
\text { João Falarz e } \\
\text { Genoveva } \\
\text { Wisniewski Falarz, } \\
\text { nasceu em Curitiba, } \\
\text { colônia Orleans, } \\
1895 \text {. }\end{array}$ & 1953 & 1953 & $\begin{array}{l}\text { Seu pai foi professor e } \\
\text { fundador da primeira } \\
\text { escola isolada de nível } \\
\text { primário do Paraná }\end{array}$ & $\begin{array}{l}\text { Inspetor de ensino } \\
\text { primário do Estado em } \\
\text { 1927. Delegado de } \\
\text { Ensino no Paraná }\end{array}$ \\
\hline $\begin{array}{l}\text { Colégio } \\
\text { Estadual } \\
\text { João Paulo } \\
\text { II } \\
\text { Polônia } \\
\text { Xaxim }\end{array}$ & $\begin{array}{l}\text { Pontífice e } \\
\text { líder } \\
\text { religioso }\end{array}$ & $\begin{array}{l}\text { Karol Józef Wojtyła } \\
\text { nasceu em } \\
\text { Wadowice, Polônia, } \\
\text { 1920. Visitou } \\
\text { Curitiba em 1980, } \\
\text { ocasião na qual foi } \\
\text { inaugurado o } \\
\text { Bosque do Papa, em } \\
\text { sua homenagem, na } \\
\text { região do Centro } \\
\text { Cívico }\end{array}$ & 1980 & 1980 & $\begin{array}{l}\text { Papa da Igreja Católica } \\
\text { Apostólica Romana de } \\
1978 \text { a } 2005\end{array}$ & $\begin{array}{l}\text { Doutor em Filosofia e } \\
\text { fluente em } 12 \text { línguas }\end{array}$ \\
\hline
\end{tabular}

Fonte: Autoras.

\section{APÊNDICE 3: IMIGRAÇÃO ALEMÃ}

\begin{tabular}{|c|c|c|c|c|c|c|}
\hline $\begin{array}{l}\text { Nome } \\
\text { completo/ } \\
\text { Procedência } \\
\text { do } \\
\text { Sobrenome/ } \\
\text { Bairro }\end{array}$ & Profissão & Atuação & $\begin{array}{l}\text { Ano } \\
\text { de } \\
\text { Fun } \\
\text { daçã } \\
\text { o } \\
\text { Esco } \\
\text { la }\end{array}$ & $\begin{array}{l}\text { Ano } \\
\text { de } \\
\text { Nom } \\
\text { eação }\end{array}$ & Capitais Políticos & Capitais Educacionais \\
\hline $\begin{array}{l}\text { Colégio } \\
\text { Estadual } \\
\text { Professor } \\
\text { Guido } \\
\text { Straube } \\
\text { Alemanha } \\
\text { Mercês }\end{array}$ & $\begin{array}{l}\text { Naturalista, } \\
\text { Professor de } \\
\text { História } \\
\text { Natural do } \\
\text { Ginásio } \\
\text { Paranaense } \\
\text { (atual } \\
\text { Colégio }\end{array}$ & $\begin{array}{l}\text { Diretor do Ginásio } \\
\text { Paranaense de } 1932 \\
\text { a } 1937 . \text { Descendente } \\
\text { de alemães, "herdou } \\
\text { de seu avô e bisavô, } \\
\text { ambos chamados } \\
\text { Franz Josef Straube, } \\
\text { o amor pela natureza }\end{array}$ & 1965 & 1966 & $\begin{array}{l}\text { Seu filho, Ernani Costa } \\
\text { Straube, foi diretor do } \\
\text { Colégio Estadual do } \\
\text { Paraná, Secretário do } \\
\text { Departamento de } \\
\text { Estabelecimentos Penais } \\
\text { do Estado, em 1961, } \\
\text { Diretor Substituto da }\end{array}$ & $\begin{array}{l}\text { Cirurgião-dentista } \\
\text { formado em 1917, pela } \\
\text { Universidade do Paraná. } \\
\text { Membro do Templo das } \\
\text { Musas do Instituto Neo } \\
\text { Pitagórico, fundado por } \\
\text { Dario Velloso, seu } \\
\text { amigo. }\end{array}$ \\
\hline
\end{tabular}


Revista NEP, Núcleo de Estudos Paranaenses, Curitiba, v.4, n.2, dez. 2018

\begin{tabular}{|c|c|c|c|c|c|c|}
\hline & $\begin{array}{l}\text { Estadual do } \\
\text { Paraná) e } \\
\text { Professor de } \\
\text { Odontologia } \\
\text { da } \\
\text { Universidade } \\
\text { do Paraná } \\
\end{array}$ & $\begin{array}{l}\text { e, paralelamente a } \\
\text { sua carreira como } \\
\text { cirurgião de nossa } \\
\text { flora e fauna". } \\
\text { (MILLARCH) }\end{array}$ & & & $\begin{array}{l}\text { Penitenciária Central do } \\
\text { Estado, em 1962. } \\
\text { Inspetor Regional de } \\
\text { Ensino de Curitiba-1963- } \\
\text { 1964; Diretor Geral da } \\
\text { Secretara de Estado da } \\
\text { Educação-1964-1966 }\end{array}$ & \\
\hline $\begin{array}{l}\text { Colégio } \\
\text { Estadual } \\
\text { Professor } \\
\text { Algacyr } \\
\text { Munhoz } \\
\text { Maeder } \\
\text { Alemanha } \\
\text { Bairro Alto }\end{array}$ & $\begin{array}{l}\text { Engenheiro } \\
\text { Civil e } \\
\text { Professor de } \\
\text { Física e } \\
\text { Filosofia } \\
\text { pela } \\
\text { Universidade } \\
\text { Federal do } \\
\text { Paraná } \\
\end{array}$ & & 1978 & 1978 & $\begin{array}{l}\text { Membro do Conselho } \\
\text { Federal de Educação, } \\
\text { Prefeito de Curitiba }\end{array}$ & $\begin{array}{l}\text { Publicou } 20 \text { obras, foi } \\
\text { reitor da Universidade } \\
\text { Federal do Paraná de } \\
1971 \text { a } 1973\end{array}$ \\
\hline $\begin{array}{l}\text { Escola } \\
\text { Estadual } \\
\text { Isolda } \\
\text { Schimid } \\
\text { Alemanha } \\
\text { Hauer }\end{array}$ & Professora & $\begin{array}{l}\text { Nasceu em Curitiba, } \\
1902\end{array}$ & 1967 & 1967 & & $\begin{array}{l}\text { Diretora do Colégio } \\
\text { Júlia Wanderley até } \\
1966\end{array}$ \\
\hline $\begin{array}{l}\text { Colégio } \\
\text { Estadual } \\
\text { Iara } \\
\text { Bergmann } \\
\text { Alemanha } \\
\text { Ganchinho } \\
\end{array}$ & Professora & & 1992 & 1992 & & \\
\hline $\begin{array}{l}\text { Colégio } \\
\text { Estadual } \\
\text { Professora } \\
\text { Hildegard } \\
\text { Söndahl } \\
\text { Alemanha } \\
\text { Cidade } \\
\text { Industrial } \\
\end{array}$ & $\begin{array}{l}\text { Professora } \\
\text { de História }\end{array}$ & $\begin{array}{l}\text { Descendente de } \\
\text { alemães (família } \\
\text { Schmah) nascida em } \\
\text { Curitiba, casada com } \\
\text { Odinir Söndahl }\end{array}$ & 1991 & 1998 & $\begin{array}{l}\text { Fundadora do Colégio } \\
\text { Bagozzi, Portão }\end{array}$ & $\begin{array}{l}\text { Formada em Geografia e } \\
\text { História pela } \\
\text { Universidade do Paraná. } \\
\text { Atuou como professora } \\
\text { primária no Grupo } \\
\text { Escolar Caramuru }\end{array}$ \\
\hline
\end{tabular}

Fonte: Autoras.

\section{APÊNDICE 4: IMIGRAÇÃO DE OUTRAS NACIONALIDADES}

\begin{tabular}{|c|c|c|c|c|c|c|}
\hline $\begin{array}{l}\text { Nome } \\
\text { completo/ } \\
\text { Procedência } \\
\text { do } \\
\text { Sobrenome/ } \\
\text { Bairro }\end{array}$ & Profissão & Atuação & $\begin{array}{l}\text { Ano } \\
\text { de } \\
\text { Fun } \\
\text { daçã } \\
\text { o } \\
\text { Esco } \\
\text { la }\end{array}$ & $\begin{array}{l}\text { Ano } \\
\text { de } \\
\text { Nom } \\
\text { eação }\end{array}$ & Capitais Políticos & Capitais Educacionais \\
\hline $\begin{array}{l}\text { Colégio } \\
\text { Estadual } \\
\text { Gottlieb } \\
\text { Mueller } \\
\text { Suíça } \\
\text { Boqueirão }\end{array}$ & Industrial & $\begin{array}{l}\text { Vindo da Suíça em } \\
1843 \text {, Gottlieb } \\
\text { Mueller chegou ao } \\
\text { Brasil aos } 19 \text { anos, } \\
\text { inicialmente } \\
\text { morando em } \\
\text { Joinville, SC. } \\
\text { Estabeleceu-se no } \\
\text { Paraná a partir de } \\
1878 \text {. } \\
\end{array}$ & 1974 & 1974 & $\begin{array}{l}\text { Proprietário da } \\
\text { Metalúrgica Mueller. } \\
\text { Criador da Caixa Mútua } \\
\text { se assistência } \\
\text { profissional e médica aos } \\
\text { seus operários. Capitão } \\
\text { da Guarda Nacional em } \\
1889\end{array}$ & \\
\hline $\begin{array}{l}\text { Colégio } \\
\text { Estadual } \\
\text { Prieto } \\
\text { Martinez } \\
\text { Espanha/ex- } \\
\text { colônias } \\
\text { Bom Retito }\end{array}$ & Professor & Paulista & 1910 & 1932 & & $\begin{array}{l}\text { Diretor da Instrução } \\
\text { Pública do Paraná de } \\
1920 \text { a } 1925\end{array}$ \\
\hline
\end{tabular}


Revista NEP, Núcleo de Estudos Paranaenses, Curitiba, v.4, n.2, dez. 2018

\begin{tabular}{|c|c|c|c|c|c|c|}
\hline $\begin{array}{l}\text { Escola } \\
\text { Estadual } \\
\text { Ernani Vidal } \\
\text { Espanha } \\
\text { São } \\
\text { Lourenço }\end{array}$ & & Sem PPP online & & & & \\
\hline $\begin{array}{l}\text { Colégio } \\
\text { Estadual } \\
\text { Pilar } \\
\text { Maturana } \\
\text { Espanha/ex- } \\
\text { colônias } \\
\text { Bairro Alto }\end{array}$ & $\begin{array}{l}\text { Educadora e } \\
\text { freira }\end{array}$ & $\begin{array}{l}\text { Maria del Pilar } \\
\text { Maturana foi irmã } \\
\text { e educadora da } \\
\text { Congregação do } \\
\text { Sagrado Coração de } \\
\text { Jesus, Maria Pilar } \\
\text { Maturana, que } \\
\text { dedicou grande parte } \\
\text { de sua vida às } \\
\text { crianças da Escola } \\
\text { Cônego Camargo e à } \\
\text { comunidade do } \\
\text { Bairro Alto. }\end{array}$ & 1999 & 1999 & & \\
\hline $\begin{array}{l}\text { Escola } \\
\text { Estadual } \\
\text { Santo } \\
\text { Antônio } \\
\text { Portugal } \\
\text { Campo } \\
\text { Comprido } \\
\end{array}$ & & $\begin{array}{l}\text { Padre franciscano. } \\
\text { Santo António de } \\
\text { Pádua nasceu em } \\
\text { Lisboa, no início do } \\
\text { século XII }\end{array}$ & 1912 & 1917 & & \\
\hline $\begin{array}{l}\text { Colégio } \\
\text { Estadual } \\
\text { Gabriela } \\
\text { Mistral } \\
\text { Chile } \\
\text { Vila Izabel }\end{array}$ & & $\begin{array}{l}\text { Poetisa, professora e } \\
\text { diplomata chilena } \\
\text { Lucila de María del } \\
\text { Perpetuo Socorro } \\
\text { Godoy Alcayaga } \\
\text { nasceu em } 1889 \text { na } \\
\text { cidade de Vicuña, } \\
\text { Norte do Chile }\end{array}$ & 1957 & 1957 & & $\begin{array}{l}\text { Trabalhou no Ministério } \\
\text { da Educação mexicano a } \\
\text { partir de 1922, onde } \\
\text { fundou escolas e } \\
\text { bibliotecas. Em } 1926 \text { foi } \\
\text { designada secretária do } \\
\text { Instituto de Coperación } \\
\text { Intelectual de la } \\
\text { Sociedade de Naciones. } \\
\text { Primeira escritora da } \\
\text { América Latina a vencer } \\
\text { o Prêmio Nobel de } \\
\text { Literatura. Amiga de } \\
\text { Manuel Bandeira, Jorge } \\
\text { de Lima, Assis } \\
\text { Chateaubriand, Vinícius } \\
\text { de Moraes e Mário de } \\
\text { Andrade }\end{array}$ \\
\hline $\begin{array}{l}\text { Colégio } \\
\text { Estadual } \\
\text { Deputado } \\
\text { Olívio } \\
\text { Belich } \\
\text { Áustria } \\
\text { Cajuru }\end{array}$ & Juiz de Paz & $\begin{array}{l}\text { Nascido em Porto } \\
\text { Amazonas, } 1920 . \\
\text { Sobrenome de } \\
\text { Descendência } \\
\text { austríaca segundo o } \\
\text { Arquivo Público do } \\
\text { Paraná }\end{array}$ & 1973 & 1973 & $\begin{array}{l}\text { Vereador em Porto } \\
\text { Amazonas, PR, } \\
\text { Coligação PSP-PSD-PR, } \\
\text { 1951- } \\
\text { 1954; Prefeito de Porto } \\
\text { Amazonas, PSD, 1956- } \\
\text { 1959; Vereador em Porto } \\
\text { Amazonas, } \\
\text { PR, PSD, 1960-1963; } \\
\text { Deputado Estadual, } \\
\text { 1963-1966; Deputado } \\
\text { Estadual, ARENA, } \\
\text { 1966-1970 }\end{array}$ & \\
\hline $\begin{array}{l}\text { Escola } \\
\text { Estadual } \\
\text { República } \\
\text { Oriental do } \\
\text { Uruguai } \\
\text { Referência } \\
\text { ao Uruguai } \\
\text { Capão da } \\
\text { Imbuia } \\
\end{array}$ & & $\begin{array}{l}\text { Homenagem à } \\
\text { fraternal amizade } \\
\text { entre o Brasil e o } \\
\text { Uruguai e ao } \\
\text { General uruguaiano } \\
\text { de nome Marcelino } \\
\text { Bergali que passava } \\
\text { pelo governo. }\end{array}$ & 1942 & 1942 & & \\
\hline
\end{tabular}


Revista NEP, Núcleo de Estudos Paranaenses, Curitiba, v.4, n.2, dez. 2018

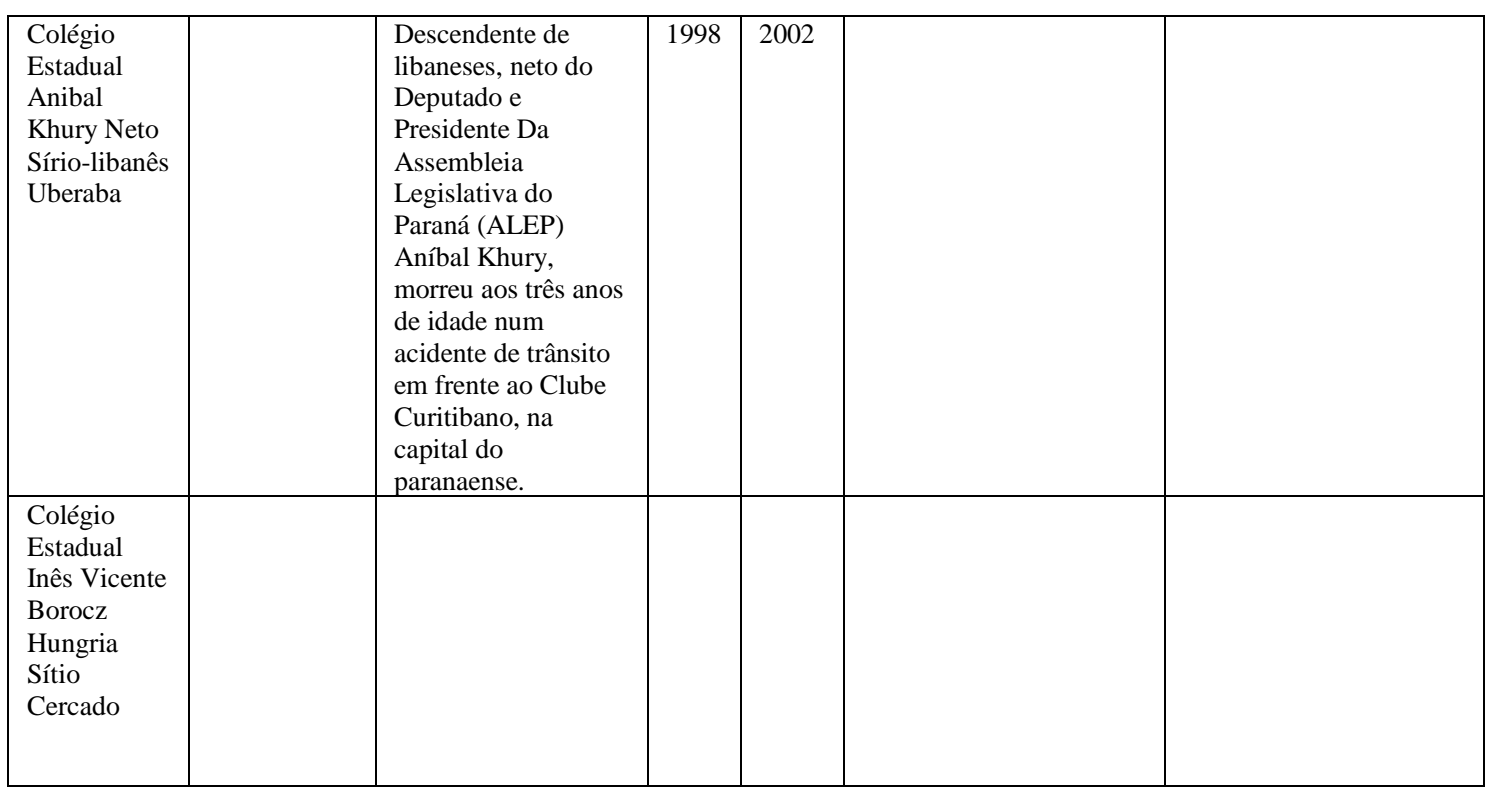

Fonte: Autoras.

\section{APÊNDICE 5: ENTIDADES CRISTÃS INTERNACIONAIS}

\begin{tabular}{|c|c|c|c|c|c|c|}
\hline $\begin{array}{l}\text { Nome } \\
\text { completo/ } \\
\text { Procedência } \\
\text { do } \\
\text { Sobrenome/ } \\
\text { Bairro }\end{array}$ & Profissão & Atuação & $\begin{array}{l}\text { Ano } \\
\text { de } \\
\text { Fun } \\
\text { daçã } \\
\text { o } \\
\text { Esco } \\
\text { la }\end{array}$ & $\begin{array}{l}\text { Ano } \\
\text { de } \\
\text { Nom } \\
\text { eação }\end{array}$ & Capitais Políticos & Capitais Educacionais \\
\hline $\begin{array}{l}\text { Colégio } \\
\text { Estadual } \\
\text { São Braz } \\
\text { São Bráz }\end{array}$ & & $\begin{array}{l}\text { Bispo Nasceu } \\
\text { em } 264 \text { em Roma } \\
\text { Homenagem ao } \\
\text { bairro }\end{array}$ & 1964 & 1964 & & \\
\hline $\begin{array}{l}\text { Escola } \\
\text { Estadual } \\
\text { Nossa } \\
\text { Senhora da } \\
\text { Salete } \\
\text { Entidade } \\
\text { cristã } \\
\text { mundial } \\
\text { Jardim } \\
\text { Social } \\
\end{array}$ & & $\begin{array}{l}\text { Fundada pelos } \\
\text { padres salestinos }\end{array}$ & 1960 & 1960 & & \\
\hline $\begin{array}{l}\text { Escola } \\
\text { Estadual } \\
\text { Nossa } \\
\text { Senhora de } \\
\text { Fátima } \\
\text { Entidade } \\
\text { cristã } \\
\text { mundial } \\
\text { Tarumã }\end{array}$ & & $\begin{array}{l}\text { Fundada pelo Padre } \\
\text { Agostinho Marochi }\end{array}$ & 1961 & 1961 & & \\
\hline
\end{tabular}


Revista NEP, Núcleo de Estudos Paranaenses, Curitiba, v.4, n.2, dez. 2018

\begin{tabular}{|c|c|c|c|c|c|c|}
\hline $\begin{array}{l}\text { Colégio } \\
\text { Estadual } \\
\text { São Paulo } \\
\text { Apóstolo } \\
\text { Entidade } \\
\text { Católica } \\
\text { Mundial } \\
\text { Uberaba } \\
\end{array}$ & & $\begin{array}{l}\text { Fundada pelo Padre } \\
\text { Júlio Saavedra, } \\
\text { vigário da Paróquia } \\
\text { São Paulo Apóstolo }\end{array}$ & 1955 & 1955 & & \\
\hline $\begin{array}{l}\text { Colégio } \\
\text { Estadual } \\
\text { Nossa } \\
\text { Senhora } \\
\text { Aparecida } \\
\text { Entidade } \\
\text { cristã } \\
\text { mundial, } \\
\text { padroeira do } \\
\text { Brasil } \\
\text { Xaxim }\end{array}$ & & & 1963 & 1963 & & \\
\hline $\begin{array}{l}\text { Colégio } \\
\text { Estadual } \\
\text { Santo } \\
\text { Agostinho } \\
\text { Entidade } \\
\text { cristã } \\
\text { mundial } \\
\text { Boqueirão }\end{array}$ & $\begin{array}{l}\text { Teólogo e } \\
\text { filóssofo do } \\
\text { cristianismo } \\
\text { Nasceu em } \\
354 \mathrm{em} \\
\text { Tagaste, } \\
\text { Numídia, } \\
\text { atual Argélia }\end{array}$ & & 1988 & 1988 & & \\
\hline $\begin{array}{l}\text { Colégio } \\
\text { Estadual } \\
\text { São Pedro } \\
\text { Apóstolo } \\
\text { Entidade } \\
\text { cristã } \\
\text { mundial } \\
\text { Xaxim }\end{array}$ & $\begin{array}{l}\text { Homenagem } \\
\text { aos } \\
\text { moradores } \\
\text { da Vila. } \\
\text { Nome } \\
\text { escolhido } \\
\text { pela } \\
\text { comunidade } \\
\text { escolar }\end{array}$ & & 1993 & 1993 & & \\
\hline $\begin{array}{l}\text { Escola } \\
\text { Estadual } \\
\text { São } \\
\text { Sebastião } \\
\text { Entidade } \\
\text { Cristã } \\
\text { Mundial } \\
\text { Umbará }\end{array}$ & $\begin{array}{l}\text { Nasceu em } \\
256 \text { em } \\
\text { Narbona } \\
\text { França. } \\
\text { Perseguido } \\
\text { imperador } \\
\text { romano } \\
\text { Diocleciano. }\end{array}$ & & 1967 & 1971 & & \\
\hline
\end{tabular}

Fonte: Autoras.

\section{Referências biográficas dos nomes de escolas}

ALMEIDA, Dino. Bandeirantes do Progresso. Curitiba: Alfa Empreendimentos do Paraná, 1968.

DENSIDADE Sobrenomes. Disponível em: http://forebears.io . Acesso em 09/07/2018.

MUZZILLO, Camila. 1001 ruas de Curitiba. Organizado por Camila Muzzillo. Curitiba. Artes \& Textos, 2011. 
PEREIRA, F.M. Casamento como estratégia de ampliação de poder: um breve estudo genealógico da família Khury. In: OLIVEIRA, R.C. (org.). Nepotismo, parentesco e mulheres. Curitiba: RM Editores, 2016.

\section{Referências biográficas dos nomes de escolas}

COLÉGIO ESTADUAL AMÂNCIO MORO

FEDERAÇÃO PARANAENSE DE FUTEBOL. Disponível em: 〈http://www.federacaopr.com.br/Paginas/Federacao/Historia.aspx\#ep>. Acesso em: $16 / 09 / 2017$.

TRE-PR. Resultado das eleições. Disponível em: <http://www.trepr.jus.br/eleicoes/resultados/resultados-de-eleicoes-municipais-tre-pr $>$. Acesso em: $16 / 09 / 2017$.

Colégio Estadual Amâncio Moro. Apresentação. Disponível em: <http://www.ctaamanciomoro.seed.pr.gov.br/modules/conteudo/conteudo.php?conteudo $=22>$. Acesso em: 16/09/2017.

COLÉGIO ESTADUAL POTY LAZAROTTO

Colégio Estadual Poty Lazarotto Disponível em: $<$ http://www.ctaceebjapottylazarotto.seed.pr.gov.br/modules/conteudo/conteudo.php?co nteudo=1>. Acesso em: 16/09/2017.

DIA de Poty Lazzarotto, o muralista com a cara Curitiba. Disponível em: <http://www.gazetadopovo.com.br/caderno-g/dia-de-poty-lazzarotto-o-muralista-coma-cara-curitiba-2nwvgpal3ck8p9h13iymqi0ia>. Acesso em: 16/09/2017.

O PARANAENSE Poty Lazarotto. Disponível em: <https://artemuralbrasil.wordpress.com/2010/06/22/o-paranaense-poty-lazzarotto/>. Acesso em: 16/09/2017.

POTY LAZAROTTO. Disponível em: <http://www.cultura.pr.gov.br/modules/conteudo/conteudo.php? conteudo=292 > . Acesso em: 16/09/2017.

POTY LAZAROTTO. Disponível em: <http://enciclopedia.itaucultural.org.br/pessoa1567/poty-lazzarotto>. Acesso em: 16/09/2017.

$<$ https://artemuralbrasil.wordpress.com/2010/06/22/o-paranaense-poty-lazzarotto/> . Acesso em: 16/09/2017. 
COLÉGIO ESTADUAL ERASMO PILOTTO.

Colégio Estadual Erasmo Pilotto. Apresentação. Disponível em: <http://www.ctaieperasmopilotto.seed.pr.gov.br/redeescola/escolas/9/690/45/arquivos/F ile/documentos/regconsrefor.pdf >. Acesso em: 16/09/2017.

ERASMO PILOTTO. Disponível em: 〈http://institutoerasmopilotto.blogspot.com.br/p/erasmo-pilotto_9269.html>. Acesso em: 16/09/2017.

VIEIRA, Carlos Eduardo. O movimento pela Escola Nova no Paraná: trajetória e idéias educativas de Erasmo Pilotto. Educar, Editora da UFPR, Curitiba, n.18, p. 53-73. 2001. Disponível em: <http://www.scielo.br/pdf/er/n18/n18a06.pdf>. Acesso em: 16/09/2017.

COLÉGIO ESTADUAL ÂNGELO GUSSO

Colégio Estadual Ângelo Gusso. Apresentação. Disponível em: <http://www.ctaangelogusso.seed.pr.gov.br/modules/conteudo/conteudo.php?conteudo= 1 >. Acesso em: 16/09/2017.

CASA do entalhe. Disponível em: <http://www.casadoentalhe.com.br/>. Acesso em: 16/09/2017.

COLÉGIO ESTADUAL JOÃO PAULO I

Colégio Estadual João Paulo I. Disponível em: $<$ http://www.ctajoaopauloi.seed.pr.gov.br/modules/conteudo/conteudo.php?conteudo=1 1 >. Acesso em: 17/09/2017.

COLÉGIO ESTADUAL MARIA CASELLI

Colégio Estadual Maria Caselli. Apresentação. Disponível em: $<$ http://www.ctamariacasselli.seed.pr.gov.br/redeescola/escolas/9/690/410/arquivos/File /PPPCasselli.pdf>. Acesso em: 16/09/2017.

COLÉGIO ESTADUAL MARIA MONTESSORI

Colégio Estadual Maria Montessori. Apresentação. Disponível em: <http://www.ctamariamontessori.seed.pr.gov.br/modules/conteudo/conteudo.php? conte

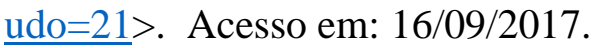

MÉDICA valorizou o aluno. Disponível em: <https://novaescola.org.br/conteudo/459/medica-valorizou-aluno>. Acesso em: $16 / 09 / 2017$.

COLÉGIO ESTADUAL SANTA GEMMA 
Revista NEP, Núcleo de Estudos Paranaenses, Curitiba, v.4, n.2, dez. 2018

Colégio Estadual Santa Gemma. Apresentação. Disponível em: <http://www.ctasantagemma.seed.pr.gov.br/modules/conteudo/conteudo.php? conteudo $=1>$. Acesso em: 16/09/2017.

COLÉGIO ESTADUAL LUIZ LOSSO

DICIONÁRIO Histórico-Biográfico CPDOC- FGV. Verbete Luis Losso. Disponível em: $\langle$ http://www.fgv.br/cpdoc/acervo/dicionarios/verbete-biografico/losso-luis〉. Acesso em: 16/09/2017.

COLÉGIO ESTADUAL DOMINGOS ZANLORENZI.

Colégio Estadual Domingos Zanlorenzi. Apresentação. Disponível em:

<http://www.ctadomingoszanlorenzi.seed.pr.gov.br/modules/conteudo/conteudo.php?co nteudo=7 >.Acesso em: 16/09/2017.

COLÉGIO ESTADUAL ÂNGELO TREVISAN

Colégio Estadual Ângelo Trevisan. Apresentação. Disponível em: <http://www.ctaangelotrevisan.seed.pr.gov.br/modules/conteudo/conteudo.php? conteud $\underline{\mathrm{o}=10}$ >. Acesso em: 16/09/2017.

BROTTON, Jerry. Uma história do mundo em doze mapas. Rio de Janeiro. Zahar.

COLÉGIO ESTADUAL ÂNGELO VOLPATO

Colégio Estadual Ângelo Volpato. Apresentação. Disponível em: $<$ http://www.ctaangelovolpato.seed.pr.gov.br/modules/conteudo/conteudo.php?conteud o=14>. Acesso em: 16/09/2017.

COLÉGIO ESTADUAL PADRE COBALCCHINI

Colégio Estadual Padre Cobalcchini. Apresentação. Disponível em: <http://www.ctacolbacchini.seed.pr.gov.br/modules/conteudo/conteudo.php?conteudo= 1>. Acesso em: 16/09/2017.

COLÉGIO ESTADUAL FRANCISCO ZARDO

Colégio Estadual Francisco Zardo. Apresentação. Disponível em: $<$ http://www.ctafranciscozardo.seed.pr.gov.br/modules/conteudo/conteudo.php?conteud $\underline{0=12}>$. Acesso em: 16/09/2017.

COLÉGIO ESTADUAL JOÃO TURIN

Colégio Estadual João Turin. Apresentação. Disponível em: <http://www.ctajoaoturin.seed.pr.gov.br/modules/conteudo/conteudo.php?conteudo=15 >. Acesso em: 16/09/2017.

QUEM foi: João Turin. Disponível em: <http://curitibaspace.com.br/quem-foi-joaoturin/ >. Acesso em: 16/09/2017. 
JOÃO Turin, precursor da escultura no Paraná. Disponível em: <http://www.gazetadopovo.com.br/educacao/joao-turin-precursor-da-escultura-noparana-bj1t0k5sx2rbfk6looaof0q4u >.Acesso em: 16/09/2017.

COLÉGIO ESTADUAL JOSÉ BUSNARDO

Colégio Estadual José Busnardo. Apresentação. Disponível em: <http://www.ctajosebusnardo.seed.pr.gov.br/redeescola/escolas/9/690/878/arquivos/File /PPP.pdf >. Acesso em: 16/09/2017.

COLÉGIO ESTADUAL DOM ORIONE

Colégio Estadual Dom Orione. Apresentação. Disponível em: <http://www.ctadomorione.seed.pr.gov.br/redeescola/escolas/9/690/4490/arquivos/File/ PPP.pdf $>$. Acesso em: 16/09/2017.

SANTO do dia São Luís Orione, grande exemplo de santidade. Disponível em: $<$ https://santo.cancaonova.com/santo/sao-luis-orione-grande-exemplo-de-santidade/>.

Acesso em: 16/09/2017.

COLÉGIO ESTADUAL JOÃO BETTEGA

Colégio Estadual João Bettega. Apresentação. Disponível em: <http://www.ctajoaobettega.seed.pr.gov.br/redeescola/escolas/9/690/1106/arquivos/File/ ppp_montado.pdf Acesso em 16.set.2017>. Acesos em: 19/09/2017.

COLÉGIO ESTADUAL GUIDO VIARO.

GUIDO Viaro- Apresentação. Disponível em: <http://centrodeartesguidoviaro.com.br/?page $\mathrm{id}=7$ >. Acesso em: 16/09/2017.

GUIDO Viaro- Biografia. Disponível em: $<$ http://www.cultura.pr.gov.br/modules/conteudo/conteudo.php? conteudo=312 $>$. Acesso em: 16/09/2017.

GUIDO VIARO. Disponível em: 〈http://enciclopedia.itaucultural.org.br/pessoa9385/guido-viaro>. Acesso em: 16/09/2017.

COLÉGIO ESTADUAL NATÁLIA REGINATO

Colégio Estadual Natália Reginato. Apresentação. Disponível em: <http://www.ctanataliareginato.seed.pr.gov.br/modules/conteudo/conteudo.php?conteud $\underline{0=1}>$. Acesso em: 16/09/2017.

COLÉGIO ESTADUAL MÁXIMO ATÍLIO ASINELLI

Colégio Estadual Professor Máximo Atílio Asinelli. Apresentação. Disponível em: <http://www.ctamaximoasinelli.seed.pr.gov.br/modules/conteudo/conteudo.php?conteu $\underline{\text { do }=25}>$. Acesso em: 16/09/2017. 
Revista NEP, Núcleo de Estudos Paranaenses, Curitiba, v.4, n.2, dez. 2018

COLÉGIO ESTADUAL PAULINA BORSARI

Colégio Estadual Paulina Borsari. Apresentação. Disponível em: <http://www.ctapaulinaborsari.seed.pr.gov.br/modules/conteudo/conteudo.php?conteud o=10>. Acesso em: 16/09/2017.

FRANCISCO BORSARI. Disponível em: <http://tomasbarreiros.com.br/wpcontent/uploads/2016/07/Francisco-Borsari-Netto.pdf >. Acesso em: 16/09/2017.

COLÉGIO ESTADUAL PIO LANTERI

Colégio Estadual Pio Lanteri. Apresentação. Disponível em: $\langle$ http://www.ctapiolanteri.seed.pr.gov.br/modules/conteudo/conteudo.php?conteudo=1 > .Acesso em: 16/09/2017.

COLÉGIO ESTADUAL JOÃO MAZZAROTTO

Colégio Estadual João Mazzarotto. Projeto Político-Pedagógico. Disponível em: <http://www.ctajoaomazzarotto.seed.pr.gov.br/redeescola/escolas/9/690/789/arquivos/F ile/PPP_ATUALIZADO.pdf>. Acesso em: 1609/2017.

CARNEIRO JR., R. A. A Liga Eleitoral Católica e a participação da Igreja Católica. História: Questões \& Debates, Curitiba, n. 55, p. 137-161, jul./dez. 2011. Editora UFPR

\section{COLÉGIO ESTADUAL CLÁUDIO MORELLI}

Colégio Estadual Cláudio Morelli. Disponível em: <http://www.ctaclaudiomorelli.seed.pr.gov.br/modules/conteudo/conteudo.php?conteud $\mathrm{o}=12$ >. Acesso em: 16/09/2017.

〈http://www.ctaclaudiomorelli.seed.pr.gov.br/redeescola/escolas/9/690/4679/arquivos/F ile/ppp2\%20-\%202009.pdf >. Acesso em: 16/09/2017.

\section{COLÉGIO ESTADUAL HASDRUBAL BELLEGARD}

Colégio Estadual Hasdrubal Bellegard. Disponível em: <http://www.ctahasdrubalbellegard.seed.pr.gov.br/modules/conteudo/conteudo.php?con teudo=12 >. Acesso em: 16/09/2017.

COLÉGIO ESTADUAL JOSÉ FRESSATO

Colégio Estadual José Fressato. Apresentação. Disponível em: <http://www.ctajosefressato.seed.pr.gov.br/modules/conteudo/conteudo.php?conteudo= $17>$. Acesso em: 16/09/2017.

\section{COLÉGIO ESTADUAL RODOLPHO ZANINELLI}

Colégio Estadual Rodolpho Zaninelli. Projeto Político-Pedagógico. Disponível em: <http://www.ctarodolphozaninelli.seed.pr.gov.br/redeescola/escolas/9/690/7856/arquivo s/File/Projeto_Politico_Pedagogico1.pdf >. Acesso em: 16/09/2017. 
NE P Revista NEP, Núcleo de Estudos Paranaenses, Curitiba, v.4, n.2, dez. 2018

\section{COLÉGIO ESTADUAL JOÃO WISLINSKI}

Colégio Estadual João Wislinski. Apresentação. Disponível em: <http://www.ctajoaowislinski.seed.pr.gov.br/modules/conteudo/conteudo.php? conteudo =1>. Acesso em 16.set.2017.

COLÉGIO ESTADUAL SEBASTIÃO SAPORSKI

ANGULSKI, Nazareno. Perfil dos Primeiros Imigrantes que Chegaram ao Brasil. (pdf). Curitiba: Publicação da Missão Católica no Brasil. Polonius - Revista de Reflexão Brasil-Polonia. Ano IV (7-8), 2013.

SEBASTIAN Edmund Saporski. Disponível em: $<$ http://ipsb.nina.gov.pl/a/biografia/sebastian-edmund-saporski-wos-saporskipierwotnie-wos\#text >. Acesso em: 16/09/2017.

COLÉGIO ESTADUAL PAULO LEMINSKI

Colégio Estadual Paulo Leminski. Apresentação. Disponível em: <http://www.ctapauloleminski.seed.pr.gov.br/redeescola/escolas/9/690/9026/arquivos/F ile/PPP_2012_atualizado.pdf >. Acesso em: 16/09/2017.

PAULO LEMINSKI. Disponível em: 〈https://www.ebiografia.com/paulo_leminski/ > Acesso em: 16/09/2017.

COLÉGIO ESTADUAL SILVESTRE KANDORA

Colégio Estadual Silvestre Kandora. Apresentação. Disponível em: <http://www.ctasilvestrekandora.seed.pr.gov.br/modules/conteudo/conteudo.php?conte udo=1 >. Acesso em: 16/09/2017.

COLÉGIO ESTADUAL SEGISMUNDO FALARZ

Colégio Estadual Segismundo Falarz. Disponível em: <http://www.ctasegismundo.seed.pr.gov.br/redeescola/escolas/9/690/975/arquivos/File/ PPP.pdf $>$. Acesso em: 16/09/2017.

COLÉGIO ESTADUAL PAPA JOÃO PAULO II

Colégio Estadual Papa João Paulo II. Apresentação. Disponível em: $<$ http://www.ctajoaopauloii.seed.pr.gov.br/modules/conteudo/conteudo.php? conteudo= 1>. Acesso em: 16/09/2017.

COLÉGIO ESTADUAL ALGACYR MUNHOZ MAEDER.

Colégio Estadual Algacyr Munhoz Maeder. Apresentação. Disponível em: <http://www.ctaalgacyrmaeder.seed.pr.gov.br/modules/conteudo/conteudo.php?conteud $\underline{\mathrm{o}=7}>$. Acesso em: 16/09/2017.

GALERIA de ex-reitores da UFPR. Disponível em: $<$ http://www.ufpr.br/portalufpr/galeria-de-ex-reitores-da-ufpr/>. Acesso em: $16 / 09 / 2017$. 


\section{COLÉGIO ESTADUAL PROFESSOR GUIDO STRAUBE}

Colégio Estadual Colégio Estadual Professor Guido Straube. Apresentação. Disponível em:

<http://www.ctaguidostraube.seed.pr.gov.br/modules/conteudo/conteudo.php?conteudo $=\underline{35}>$. Acesso em: 16/09/2017.

PROJETO POLÍTICO-PEDAGÓGICO. Disponível em: <http://www.ctaguidostraube.seed.pr.gov.br/redeescola/escolas/9/690/96/arquivos/File/ PPP.pdf > . Acesso em: 16/09/2017.

CENTENÁRIO de Guido Straube, um homem que amou a nossa natureza. Artigo de Aramis Millarch originalmente publicado em 26 de junho de 1990. Disponível em: $<$ http://www.millarch.org/artigo/centenario-de-guido-straube-um-homem-que-amounossa-natureza >. Acesso em: 16/09/2017.

IHGB Ernani Costa Straube. Disponível em:

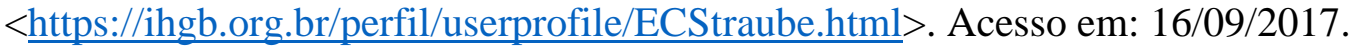

COLÉGIO ESTADUAL ISOLDA SCHIMID

Colégio Estadual Isolda Schimid. Apresentação. Disponível em: $<$ http://www.ctaisoldaschmid.seed.pr.gov.br/modules/conteudo/conteudo.php?conteudo $=12>$.Acesso em: 16/09/2017.

COLÉGIO ESTADUAL IARA BERGMANN

Colégio Estadual Iara Bergmann. Disponível em: $<$ http://www.ctaiarabergmann.seed.pr.gov.br/modules/noticias/>. Acesso e: $\mathrm{m}$ 16/09/2017.

COLÉGIO ESTADUAL PROFESSORA HILDEGARD SÖNDAHL

Colégio Estadual Professora Hildegard Sondahl. Apresentação. Disponível em: $<$ http://www.ctahildegardsondahl.seed.pr.gov.br/modules/conteudo/conteudo.php?conte

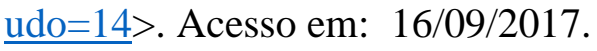

COLÉGIO ESTADUAL OLÍVIO BELICH

Colégio Estadual Olívio Belich. Regimento Escolar. Disponível em: $<$ http://www.ctaoliviobelich.seed.pr.gov.br/modules/conteudo/conteudo.php? conteudo= 1 >. Acesso em: 16/09/2017.

\section{COLÉGIO ESTADUAL AVELINO VIEIRA}

PEREIRA, Thulio Cícero Guimarães. Bancos e banqueiros, sociedade e política: José Eduardo de Andrade Vieira e o Bamerindus (1981 a 1994). V Workshop empresa, empresários e sociedade: o mundo empresarial e a questão social. Porto Alegre, 2 a 5 de maio de 2006 -PUC-RS. Disponível em: $<$ https://www.fee.rs.gov.br/5workshop/pdf/gt03 thulio.pdf $>$. Acesso em: 16/09/2017. 
Revista NEP, Núcleo de Estudos Paranaenses, Curitiba, v.4, n.2, dez. 2018

COLÉGIO ESTADUAL GOTTILIEB MUELLER

Colégio Estadual Gottilieb Mueller. Disponível em:

<http://www.ctagottliebmueller.seed.pr.gov.br/redeescola/escolas/9/690/2170/arquivos/

File/ppp.pdf $>$. Acesso em: 16/09/2017.

COLÉGIO ESTADUAL PAPA JOÃO PAULO II

Colégio Estadual Papa João Paulo II. Disponível em: <http://www.ctajoaopauloii.seed.pr.gov.br/modules/conteudo/conteudo.php? conteudo= 1 >. Acesso em: 16/09/2017.

COLÉGIO ESTADUAL TEOBALDO KLETEMBERG

Colégio Estadual Teobaldo Kletemberg. Apresentação. Disponível em: $<$ http://www.ctateobaldo.seed.pr.gov.br/modules/conteudo/conteudo.php? conteudo $=60$

>. Acesso em: 16/09/2017.

COLÉGIO ESTADUAL PILAR MATURANA

Colégio Estadual Pilar Maturana. Projeto Político-Pedagógico. Disponível em: <http://www.ctapilarmaturana.seed.pr.gov.br/redeescola/escolas/9/690/10962/arquivos/ File/PPP.pdf > . Acesso em: 16/09/2017.

COLÉGIO ESTADUAL NOSSA SENHORA DA SALETE

Colégio Estadual Nossa Senhora da Salete. Histórico. Disponível em: $<$ http://www.ctansdasalete.seed.pr.gov.br/modules/conteudo/conteudo.php? conteudo=1 \# >. Acesso em: 16/09/2017.

COLÉGIO ESTADUAL NOSSA SENHORA DE FÁTIMA

Colégio Estadual Nossa Senhora de Fátima. Apresentação. Disponível em: $<$ http://www.ctansdefatima.seed.pr.gov.br/modules/conteudo/conteudo.php? conteudo=9 $>$. Acesso em: 16/09/2017.

COLÉGIO ESTADUAL SANTO ANTÔNIO

Colégio Estadual Santo Antônio. Projeto Político-Pedagógico. Disponível em: $<$ http://www.iuvsantoantonio.seed.pr.gov.br/redeescola/escolas/25/1020/13/arquivos/Fil e/PROJETO.pdf >. Acesso em: 16/09/2017.

COLÉGIO ESTADUAL SÃO BRAZ

Colégio Estadual São Braz. Apresentação. Disponível em: $<$ http://www.ctasaobraz.seed.pr.gov.br/modules/conteudo/conteudo.php? conteudo=33.

>. Acesso em: 16/09/2017.

COLÉGIO ESTADUAL REPÚBLICA ORIENTAL DO URUGUAIColégio Estadual República Oriental do Uruguai. Apresentação. Disponível em: <http://escolauruguaicuritiba.com.br/home/o-colegio/>. Acesso em: 16/09/2017.

COLÉGIO ESTADUAL SANTA ROSA 
Revista NEP, Núcleo de Estudos Paranaenses, Curitiba, v.4, n.2, dez. 2018

Colégio Estadual Santa Rosa. Apresentação. Disponível em: <http://www.ctasantarosa.seed.pr.gov.br/modules/conteudo/conteudo.php?conteudo=1\# ancora $>$. Acesso em: 16/09/2017.

COLÉGIO ESTADUAL SÃO PAULO APÓSTOLO

Colégio Estadual São Paulo Apóstolo. Apresentação. Disponível em: <http://www.ctaspauloapostolo.seed.pr.gov.br/modules/conteudo/conteudo.php?conteud $\underline{\mathrm{o}=7}>$. Acesso em: 16/09/2017.

COLÉGIO ESTADUAL SANTO AGOSTINHO

Colégio Estadual Santo Agostinho. Apresentação. Disponível em: <http://www.ctasantoagostinho.seed.pr.gov.br/modules/conteudo/conteudo.php?conteud $\underline{\mathrm{o}=1}$. >. Acesso em: 16/09/2017.

COLÉGIO ESTADUAL SÃO PEDRO APÓSTOLO

Colégio Estadual São Pedro Apóstolo. Político-Pedagógico. Disponível em:

<http://www.ctaspedroapostolo.seed.pr.gov.br/redeescola/escolas/9/690/9034/arquivos/ File/PPPCESPA2010.pdf. . . Acesso em: 16/09/2017.

COLÉGIO ESTADUAL SÃO SEBASTIÃO

Colégio Estadual São Sebastião. Apresentação. Disponível em: $<$ http://www.ctasaosebastiao.seed.pr.gov.br/modules/conteudo/conteudo.php?conteudo $=18>$. Acesso em: 16/09/2017.

COLÉGIO ESTADUAL PRIETO MARTINEZ.

Colégio Estadual Prieto Martinez. Apresentação. Disponível em: <http://www.ctaprietomartinez.seed.pr.gov.br/modules/conteudo/conteudo.php?conteud $\underline{\mathrm{o}=1}>$. Acesso em: 16/09/2017.

COLÉGIO ESTADUAL GABRIELA MISTRAL

Colégio Estadual Gabriela Mistral Apresentação. Disponível em: $<$ http://www.ctagabrielamistral.seed.pr.gov.br/modules/conteudo/conteudo.php?conteud $\underline{\mathrm{o}=7}>$. Acesso em: 16/09/2017.

GABRIELA MISTRAL. Disponível em: <https://www.ebiografia.com/gabriela_mistral/ >. Acesso em: 16/09/2017.

COLÉGIO ESTADUAL DORACY CEZARINO.

Colégio Estadual Doracy Cezarino. Apresentação. Disponível em: $<$ http://www.ctadoracycezarino.seed.pr.gov.br/redeescola/escolas/9/690/860/arquivos/Fi le/PPP_DORACY_CEZARINO>. Pdf. Acesso em: 16/09/2017.

Recebido: 10 out. 2018

Aceito: 18 out. 2018 